\title{
INTERACTIVE COMPUTER APPLICATION FOR PREDICTING PERFORMANCE INDICATORS OF A TRACTOR-CHISEL PLOW SYSTEM IN C-SHARP ENVIRONMENT
}

\author{
Abdulwahed M. Aboukarima*
}

\begin{abstract}
An interactive computer application in C-Sharp language was developed to predict the performance indicator of a tractor-chisel plow system. Moreover, the purpose of such application was to aid agricultural engineers in the field of farm machinery management to select suitable inputs to make proper matching of a tractor and a chisel plow. The required equations were formulated using the obtained weights from a trained artificial neural network model that trained using actual data field experiments. The application predicts actual field capacity (ha/h) and fuel consumption per unit area (lit/ha). Tractor loading factor was the main issue in the present application since it was used as a regulator for determination of the required draft. The application displays a chart during simulation to show the intersect point between both specific fuel consumption calculated by the application and specific fuel consumption calculated using the equation of ASABE standard. Overall energy efficiency in the range of 10-20\% was acted to select the optimum values of the affecting parameters. The application outputs include theoretical field capacity, actual field capacity, field efficiency, fuel consumption per unit area, fuel consumption, energy required based on fuel consumption, draft, unit draft per unit plow width, unit draft per unit plowing area, draft power (drawbar power), energy required based on draft requirements, loafing factor, calculated specific fuel consumption, specific fuel consumption based on ASABE equation and overall energy efficiency.
\end{abstract}

*Senior Researcher, Agricultural Engineering Research Institute, Agricultural Research Centre, Egypt. 
For validation the developed C-Sharp application, data from previous study was utilized for chisel plow-tractor system operated in specific condition, and the simulated draft was $16.73 \mathrm{kN}$ (calculated specific fuel consumption and specific fuel consumption based on ASABE equation was 0.53 lit $/ \mathrm{kWh}$ ) and the loading factor was 0.62. The relative error between actual and simulated drat was 16\%. The developed application is appropriate for farm machinery management, educational and research purposes. It is user-friendly and could be run on Windows desktop without C-Sharp environment. The application could be edited and/or updated to predict performance indicators of other tractor-tillage implement systems.

\section{INTRODUCTION}

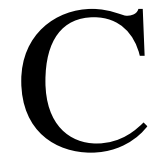
hisel plow is considered to be a primary tillage implement because it is mainly used for the initial soil working operations (Srivastava et al., 1993). It is widely used by Egyptian farmers to reduce soil strength and to cover plant materials (Ahmed, 2011). Moreover, it generally has odd number of shanks such as 5, 7,9 and they connected on two or three rows in the frame (Gulsoylu et al., 2012). On the other hand, operation performance data of a chisel plow is essential to optimize its operation and to reduce the cost of tillage process (AlSuhaibani and Ghaly, 2010). However, the performance parameters of a chisel plow included measurement of draft, drawbar power, actual field capacity, field efficiency and fuel consumption (Bashir et al., 2015). These parameters could be obtained by conducting field experiments using expensive instrumentation systems (Korayem et al., 1985; ElAshry et al., 1994; Ismail and Burkhardt, 1993; Al-Suhaibani and AlJanobi, 1997; Mohamed et al., 2001; Naderloo et al., 2009; AlSuhaibani et al., 2010; Younis et al., 2010; Askari et al., 2011; Altinigik, 2012; Askari and Khalifahamzehghasem, 2013 Ranjbarian et al., 2015). Additionally, empirical mathematical models are available in literature which can be utilized to get draft requirements, fuel consumption of tillage implements and field capacity as reported by different research papers (Gee-Clough et al., 1978; Younis and ElAshry, 1993; Sahu and Raheman, 2006). Moreover, the famous model 
for estimating draft requirements for different tillage implements at different working conditions is reported by American Society of Agricultural Engineers standard (ASABE, 2000). However, the empirical mathematical models are the way to estimate the multiple effects of alternative operating variables that affect the performance indicators of the tillage implements. These operating variables are implement width, operating depth and plowing speed (Kepner et al., 1978; Macmillan, 2002), soil moisture content (Rashidi et al., 2013; Al-Suhaibani et al., 2015; Tayel et al., 2015).

Due to there are several variables that affect the performance of tillage implements, besides, draft requirements also depend on soil conditions, soil type and the implement type (Upadhyaya et al., 1984; Grisso et al., 1994). Thus the researchers have been of great interest to develop different techniques and efforts for ability to predict the performance indicators of farm machinery units during field operations (Grisso et al. 2006). One of these efforts is to model the draft and fuel requirements in tillage operations for optimizing tractor-implement systems (Serrano Joao et al., 2005). In Addition, computer programs have been developed to determine the optimal operation of agricultural tractors and machine system using Visual C language (Al-Hamed and Al-Janobi, 2001a; 2001b). Moreover, spreadsheets and dimensional analysis could also be utilized for tractor performance prediction and performance indicators estimation for chisel plow tractor combination (Al-Hamed et al., 1994; Al-Janobi et al., 2010; Moeenifar et al., 2013).

Prediction models programmed by computer languages could be a successful tool to save time and field experiments (Catalan et al., 2008). They represent a necessarily cost-free tool to the determination of the relative importance of a number of variables affecting actual tractorimplement systems operation to reduce the costs of tillage management (Battiato et al., 2013). So, considerable research has been conducted to develop computer based models to determine performance indicator of tractors and farm implements. Omid (2006) and Abbaspour-Gilandeh et al. (2007) used visual basic environment to develop Graphical User Interfaces computer program to predict the performance indicators as well 
the tractor's specific fuel consumption for agricultural soils. Eldoma (2008) developed a computer program on Turbo Pascal for farm machinery power estimation. The program was broken down into three major sections: the heading, the declarations and the block. The program used multi types of variables and constants for performing power calculations. Sahu and Raheman (2008) developed a decision support system in Visual Basic 6.0 programming language for matching tillage implements with 2-wheel drive (2WD) tractors for predicting the field performance of tractor- implement system. Al-Hamed et al. (2010) developed a comprehensive and easy to use computer program for the purpose of determining the farm energy requirements. The program was designed with visual $\mathrm{C}++$ language. Hassan et al. (2011) developed a program for predicting performance of agricultural machinery in visual basic. The program predicts of field efficiency, field capacity, draft power required to operate machines and power take-off (PTO) power. Canakci et al. (2011) developed computer software to determine optimum size of mechanization vehicles used in farms. They employed Visual Basic to build the program. Mehta et al. (2011) developed a decision support system for selection of a tractor-implement system. Mohamed et al. (2011) developed an agricultural machinery performance program that predicts field efficiency, field capacity, selection of optimum equipment, draft power required to operate machines to meet the user requirements for machinery management and as educational and research tool. The program was written in Visual Basic programming language as userfriendly interactive program. Ishola et al. (2010) developed objectoriented and user friendly application program for predicting the performance of a tractor-implement system utilizing Visual C++ environment containing several windows that serve specific functions in the development process. Pranav et al. (2012) developed user friendly software for predicting the performance of power tiller to meet requirements in educational and research organizations by using visual basic. Park et al. (2012) developed a simulation program for the prediction of tractive performance of a tractor by applying widely used empirical models for tractive performance prediction of single tire. Patel et al. (2012) developed a decision support system in Visual Basic 6.0 
programming language for $2 \mathrm{WD}$ tractors. The decision support system provides intuitive user interfaces by linking databases such as tractor parameters, tire and implement specifications, soil and operating conditions to support the decision for selection of tractor-implement system. Zarini et al. (2013) developed decision support software in Visual Basic 6.0 programming language for matching and selecting implements with tractors and time management of farm operations. This software had databases including variety of tractor models and implements sizes. Al-Hamed et al. (2014) built a program for predicting performance of tillage implements in visual basic based on trained artificial neural network model. The program was designed to predict the required draft and energy of chisel, moldboard and disk plows. Zaied et al. (2014) developed a computer program in $\mathrm{C}++$ programming language to predict implement performance parameters. These parameters were total field time, theoretical field capacity, effective field capacity and field efficiency. The program was built, compiled and was then debugged. Zaied et al. (2016) developed a program using $\mathrm{C}++$ programming language to study effect of tool depth and width on angle of soil failure plane, soil cutting coefficients, soil resistance force and power requirements in three-dimensional soil cutting.

Simulation programs in the field of farm machinery could be used to estimate performance data of tillage implements. Also, they could be used to study the relative importance of many variables affecting field performance of tillage implements without conducting expensive, as well as time consuming, field tests (Hassan et al., 2011). On the other hand, there is a rapid progress in developing interactive application software to facilitate the interaction between users and computers (Hassan et al., 2011). However, such interactive application software is effective and simple to access, by users than programs developed in traditional programming languages (Al-Hamed and Al-Janobi, 2001b). Additionally, most of the developed interactive applications that predict tractor-implement field performance are depended on standards equations of American Society of Agricultural and Biological Engineers. Thus, the objective of this study was to develop an interactive computer application for predicting performance indicators of a tractor-chisel plow unit in $\mathrm{C}$ - 
Sharp language. The required equations were formulated using the obtained weights from a trained artificial neural network model that trained using actual data from field experiments. The application predicts actual field capacity and fuel consumption per unit area. Moreover, a loop was developed inside the application to determine the draft requirements based on altering tractor loading factor until both specific fuel consumption calculated by the developed C-Sharp application and specific fuel consumption calculated based on the equation developed by ASABE (2000) are equal.

\section{MATERIALS AND METHODS}

\subsection{The required equations for developing C-Sharp application}

The artificial neural network (ANN) model was trained using actual data from field experiments. The inputs to the ANN model were tractor power $(\mathrm{X} 1, \mathrm{~kW})$, plow width $(\mathrm{X} 2, \mathrm{~m})$, plowing depth $(\mathrm{X} 3, \mathrm{~cm})$, plowing speed $(\mathrm{X} 4, \mathrm{~km} / \mathrm{h})$, sand percentage $(\mathrm{X} 5, \%)$, silt percentage $(\mathrm{X} 6, \%)$, clay percentage $(\mathrm{X} 7, \%)$, initial soil moisture content $(\mathrm{X} 8, \mathrm{db} \%)$ and initial soil bulk density $\left(X 9, \mathrm{~g} / \mathrm{cm}^{3}\right)$. The outputs from the ANN model were actual field capacity (ha/h) and fuel consumption per unit area (lit/ha) of a tractor-chisel plow unit. The artificial neural network used in the present study was characterized by the different parameters including: network layers are 3, input nods are 9, output nodes are 2, one hidden layer having 30 nodes, transfer function is sigmoid, learn rate is 0.010402 and momentum is 0.8 (Al-Janobi et al., 2010). Typically, a minimum of three layers which are the input layer, the hidden layer and the output layer is required to develop an ANN system (Figure 1). The input contains nodes that correspond to input variables while the output contains nodes that correspond to output variables (Kaul et al., 2005). The input layer is used to distribute the inputs to a number of hidden layers and the output of which is connected to an output layer, where the outputs of units are connected to the inputs of the next via connection weight (Marchant et al., 2002). In simpler way, the weighted connections allow data to move between layers through it, where the node accepts data from previous layer and calculates a weighted sum of all its net inputs: 
$t_{i}=\sum_{j=1}^{n}\left(w_{i j} \times x_{j}+b_{i}\right)$

Where, $n$ is the number of inputs, $w$ is the weight of connection between node $\mathrm{i}$ and $\mathrm{j}, x$ is the input from node $\mathrm{j}$, and $b_{\mathrm{i}}$ is a bias. In order to calculate the node output $O_{i}$, a transfer function $f_{i}$ is then applied to the weighed value:

$O_{i}=f\left(t_{i}\right)$

For calculating fuel consumption per unit area and actual field capacity, each input was normalized and the equations for computing the normalized value of each input were as follows:

$\mathrm{X} 1 \mathrm{~N}=(($ Tractor Power -25.35$) *(0.7) /(104.40-25.35))+0.15$

$\mathrm{X} 2 \mathrm{~N}=(($ Plow width -1.35$) *(0.7) /(3.40-1.35))+0.15$

$\mathrm{X} 3 \mathrm{~N}=(($ Plowing depth -7.06$) *(0.7) /(30.00-7.06))+0.15$

$\mathrm{X} 4 \mathrm{~N}=(($ Plowing speed -2.00$) *(0.7) /(6.92-2.00))+0.15$

$\mathrm{X} 5 \mathrm{~N}=(($ Sand -11.38$) *(0.7) /(80.00-11.38))+0.15$

$\mathrm{X} 6 \mathrm{~N}=(($ Silt -11.00$) *(0.7) /(55.2011 .00))+0.15$

$\mathrm{X} 7 \mathrm{~N}=(($ Clay -9.00$) *(0.7) /(53.20-9.00))+0.15$

$\mathrm{X} 8 \mathrm{~N}=(($ Initial soil moisture content -7.30$) *(0.7) /(50.20-7.30))+0.15 \ldots .(10)$

$\mathrm{X} 9 \mathrm{~N}=(($ Initial soil bulk density -1.17$) *(0.7) /(1.86-1.17))+0.15 \ldots .(11)$

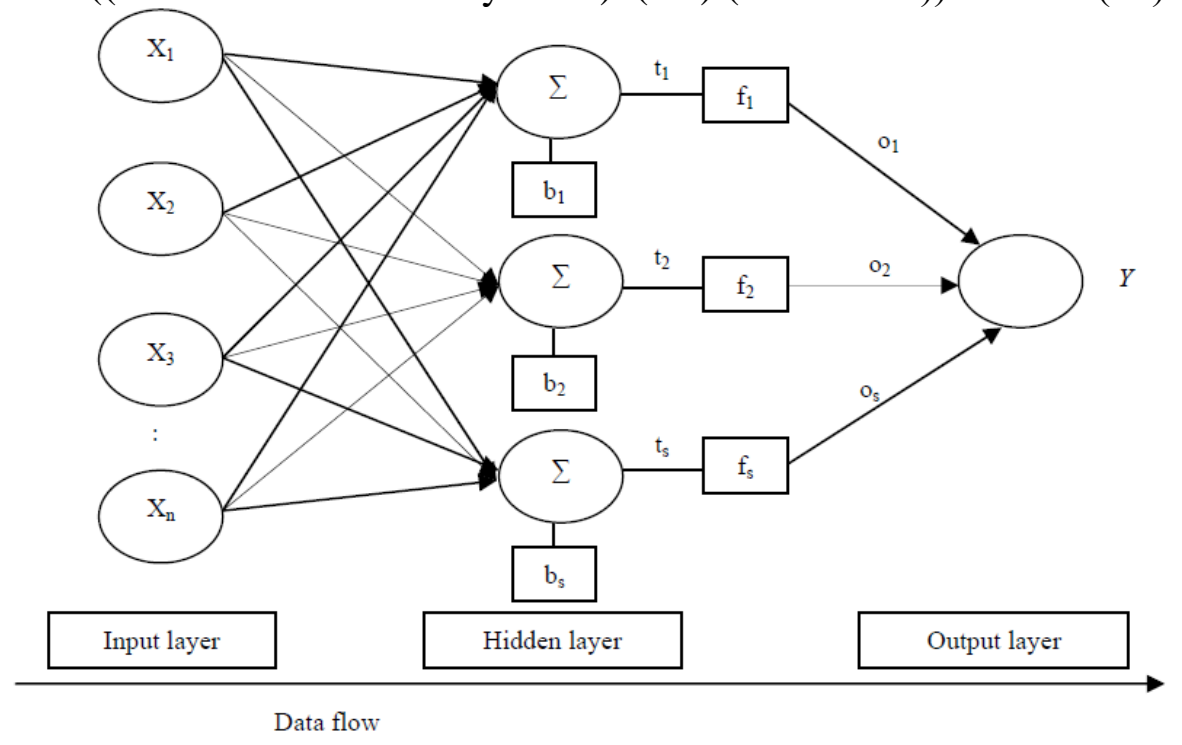

Figure (1). Layers and connection of a feed-forward back propagation ANN. 
Then summation equations as indicated in Eq. (1) were computed for fuel consumption per unit area by the help of connection weight values obtained from the ANN model (Table 1). They were 30 equations as follows:

SUM1 $=0.39722 * \mathrm{X} 1 \mathrm{~N}+0.12486 * \mathrm{X} 2 \mathrm{~N}-4.86207 * \mathrm{X} 3 \mathrm{~N}+12.51644 * \mathrm{X} 4 \mathrm{~N}$ $+1.28854 * \mathrm{X} 5 \mathrm{~N}+0.73622 * \mathrm{X} 6 \mathrm{~N}-0.39392 * \mathrm{X} 7 \mathrm{~N}-4.85972 * \mathrm{X} 8 \mathrm{~N}$ $+5.4005^{*} \mathrm{X} 9+1.96082$

$\mathrm{SUM} 30=0.87729 * \mathrm{X} 1 \mathrm{~N}-0.26943 * \mathrm{X} 2 \mathrm{~N}-1.85397 * \mathrm{X} 3 \mathrm{~N}+1.8802 * \mathrm{X} 4 \mathrm{~N}$ $-1.89565 * \mathrm{X} 5 \mathrm{~N}+2.60764 * \mathrm{X} 6 \mathrm{~N} 1.40695 * \mathrm{X} 7 \mathrm{~N}+1.61195 * \mathrm{X} 8 \mathrm{~N}-$ $0.75101 * \mathrm{X} 9+0.29716$

Then in order to calculate the node output as shown in Eq.(2), a transfer function is then applied to the weighted value (they were 30 equations) as follows:

$\mathrm{F} 1=1 /((1+\mathrm{EXP}(-\mathrm{SUM} 1)))$

$\mathrm{F} 30=1 /((1+\mathrm{EXP}(-\mathrm{SUM} 30)))$.

Then again summation equation was computed for fuel consumption per unit area by the help of connection weight values obtained from the ANN model as follows:

SUMQ $=-8.02663 * \mathrm{~F} 1-0.96115 * \mathrm{~F} 2+1.18893 * \mathrm{~F} 3-0.42434 * \mathrm{~F} 4-$

$1.06352 * \mathrm{~F} 5+1.46531 * \mathrm{~F} 6+3.67216 * \mathrm{~F} 7-0.65551 * \mathrm{~F} 8$

$1.47706 * \mathrm{~F} 9+9.90728 * \mathrm{~F} 10+6.6397 * \mathrm{~F} 11-0.26946 * \mathrm{~F} 12-1.95977 * \mathrm{~F} 13-$

$1.53764 * \mathrm{~F} 14-4.09288^{*} \mathrm{~F} 15+2.0003 * \mathrm{~F} 16-10.5647 * \mathrm{~F} 17-0.90989^{*} \mathrm{~F} 18-$

$4.27277 * \mathrm{~F} 19+6.00605 * \mathrm{~F} 20-6.58363 * \mathrm{~F} 21+11.92589 * \mathrm{~F} 22-0.61813 * \mathrm{~F} 23-$

$0.38999 * \mathrm{~F} 24+4.46134 * \mathrm{~F} 25-1.30542 * \mathrm{~F} 26-1.46609 * \mathrm{~F} 27+1.04353 * \mathrm{~F} 28-$

$1.98823 * \mathrm{~F} 29+2.33077 * \mathrm{~F} 30-0.23665$.

Then node output was computed as follows:

$\mathrm{FF}=1 /((1+\mathrm{EXP}(\mathrm{SUMQ})))$.

Then the normal fuel consumption per unit area (lit/ha) will be computed as follows:

Fuel consumption per unit area $\left(Q_{F}\right.$, lit/ha $)=((\mathrm{FF}-0.15) *(74.88-$ $8.22) /(0.7))+8.22$. 
The same procedure was also applied for actual field capacity but the final connection weight values are different and the summation equation was as follows:

SUMQ1 $1.12757 * \mathrm{~F} 1+3.28986 * \mathrm{~F} 2+0.52704 * \mathrm{~F} 3-$

$1.14918 * \mathrm{~F} 4+1.7983 * \mathrm{~F} 5+2.37183 * \mathrm{~F} 6-0.35981 * \mathrm{~F} 7+1.57607 * \mathrm{~F} 8-$

6.33971*F9-0.59344*F10-0.42763*F11-2.11729*F12-

$1.73017 * \mathrm{~F} 13+0.64729 * \mathrm{~F} 14+1.50214 * \mathrm{~F} 15-0.38546 * \mathrm{~F} 16+0.51856 * \mathrm{~F} 17-$

$2.11879 * \mathrm{~F} 18+0.07551 * \mathrm{~F} 19-0.44633 * \mathrm{~F} 20-0.82182 * \mathrm{~F} 21-0.77743 * \mathrm{~F} 22-$

$0.66159 * \mathrm{~F} 23-0.36466 * \mathrm{~F} 24+0.00725 * \mathrm{~F} 25+1.17782 * \mathrm{~F} 26-$

$0.96086 * \mathrm{~F} 27+0.94193 * \mathrm{~F} 28-1.13411 * \mathrm{~F} 29+2.0885 * \mathrm{~F} 30+0.23825 \ldots$. (19)

Then node output was computed as follows:

$\mathrm{FF} 1=1 /((1+\mathrm{EXP}(-\mathrm{SUMQ} 1)))$.

Then the normal actual field capacity ( $\mathrm{ha} / \mathrm{h}$ ) will be computed as follows: Actual field capacity $(A F C$, ha/h $)=(($ FF1-0.15)*(1.68- 0.25$) /(0.7))+$ 0.25

\subsection{Calculation of performance indicators of a chisel-tractor system}

The outputs from the developed C-Sharp application were two performance indicators including effective field capacity (ha/h) and fuel consumption per unit area (lit/ha). However, fuel consumption per unit area is the measure of amount of fuel required for a given tractorimplement system to cover 1 ha.

\subsubsection{Fuel consumption}

Fuel consumption $\left(Q_{P}\right.$, lit/h) was calculated using the following relationship,

$Q_{p}=Q_{F} \times A F C$

\subsubsection{Energy requirement}

Energy requirement $(\mathrm{kWh} / \mathrm{ha})$ of a given tractor- chisel plow system was calculated using the following relationship (Hassann et al., 2009),

Energy requirement $=\frac{\text { Engine power }(k W)}{\text { Actual field capacity }(\mathrm{ha} / \mathrm{h})}$ 
Table (1). Connection weight values for Eq. (1) for fuel consumption per unit area and actual field capacity calculations.

\begin{tabular}{|c|c|c|c|c|c|c|}
\hline Inputs & $\mathrm{W}_{1 \mathrm{j}}$ & $\mathrm{W}_{2 \mathrm{j}}$ & $\mathrm{W}_{3 \mathrm{j}}$ & $\mathrm{W}_{4 \mathrm{j}}$ & $\mathrm{W}_{5 \mathrm{j}}$ & $\mathrm{W}_{6 \mathrm{j}}$ \\
\hline $\mathrm{X} 1$ & 0.39722 & -2.59718 & 0.15226 & 0.39834 & 1.10704 & 1.83383 \\
\hline $\mathrm{X} 2$ & 0.12486 & -2.74496 & 0.14251 & -0.52509 & -0.79652 & 0.95674 \\
\hline $\mathrm{X} 3$ & -4.86207 & 0.80024 & 0.33475 & -0.28979 & 0.76551 & 0.71465 \\
\hline $\mathrm{X} 4$ & 12.51644 & 2.80618 & -0.1318 & 0.58862 & 1.84167 & 0.2252 \\
\hline $\mathrm{X} 5$ & 1.28854 & 1.76009 & 0.08386 & -0.01332 & 1.26791 & 1.69606 \\
\hline $\mathrm{X} 6$ & 0.73622 & 0.59998 & -0.09897 & -0.46831 & -0.8686 & -1.26869 \\
\hline $\mathrm{X} 7$ & -0.39392 & 0.85959 & 0.02079 & -0.40584 & -0.4772 & -1.30893 \\
\hline $\mathrm{X} 8$ & -4.85972 & -1.98496 & 0.36208 & -0.22182 & -0.52989 & 0.13083 \\
\hline $\mathrm{X} 9$ & 5.4005 & -0.56073 & 0.83834 & -0.35355 & -0.22577 & 0.21203 \\
\hline Basis $\left(b_{i}\right)$ & 1.96082 & 2.23146 & -0.44346 & 0.20232 & -0.30311 & -0.34721 \\
\hline
\end{tabular}

Table (1) continue.

\begin{tabular}{|c|c|c|c|c|c|c|}
\hline Inputs & $\mathrm{W}_{7 \mathrm{j}}$ & $\mathrm{W}_{8 \mathrm{j}}$ & $\mathrm{W}_{9 \mathrm{j}}$ & $\mathrm{W}_{10 \mathrm{j}}$ & $\mathrm{W}_{11 \mathrm{j}}$ & $\mathrm{W}_{12 \mathrm{j}}$ \\
\hline $\mathrm{X} 1$ & 1.32998 & -0.02559 & 1.48799 & -1.13475 & -1.67889 & 0.59306 \\
\hline $\mathrm{X} 2$ & -2.7585 & 0.44216 & -6.00512 & -2.5489 & 0.47201 & -0.88455 \\
\hline $\mathrm{X} 3$ & 1.11137 & -0.8995 & 0.63055 & 0.77049 & -3.11167 & 0.05388 \\
\hline $\mathrm{X} 4$ & -0.03357 & -0.0549 & -2.80145 & -0.93781 & 0.01907 & -0.65772 \\
\hline $\mathrm{X} 5$ & 0.48876 & 0.23543 & 3.74265 & -3.48957 & -1.46296 & 1.39836 \\
\hline $\mathrm{X} 6$ & -0.88811 & 0.62317 & 0.18245 & 7.17023 & 5.2655 & 0.21884 \\
\hline $\mathrm{X} 7$ & -2.08343 & 0.63213 & 1.64563 & -2.41606 & -2.75351 & -0.11064 \\
\hline $\mathrm{X} 8$ & 0.83713 & 0.02579 & 0.87455 & 12.98619 & 2.34616 & -1.5697 \\
\hline $\mathrm{X} 9$ & 1.93983 & 0.50154 & -3.03682 & -5.00842 & 6.05786 & -1.24502 \\
\hline Basis $\left(b_{i}\right)$ & -0.92985 & -0.05889 & 5.13738 & -0.40234 & 0.81188 & 1.50732 \\
\hline
\end{tabular}

Table (1) continue.

\begin{tabular}{|c|c|c|c|c|c|c|}
\hline Inputs & $\mathrm{W}_{13 \mathrm{j}}$ & $\mathrm{W}_{14 \mathrm{j}}$ & $\mathrm{W}_{15 \mathrm{j}}$ & $\mathrm{W}_{16 \mathrm{j}}$ & $\mathrm{W}_{17 \mathrm{j}}$ & $\mathrm{W}_{18 \mathrm{j}}$ \\
\hline $\mathrm{X} 1$ & -0.49237 & 0.34686 & -2.18367 & -0.05577 & 1.19557 & 0.06084 \\
\hline $\mathrm{X} 2$ & 0.69674 & -0.1692 & -2.00022 & -0.08335 & -1.68696 & -1.70154 \\
\hline $\mathrm{X} 3$ & -0.85422 & -1.48651 & -2.76148 & 1.18435 & -1.23562 & 0.29931 \\
\hline $\mathrm{X} 4$ & -1.95764 & 0.13638 & 2.49323 & -0.21499 & -0.414 & 1.18852 \\
\hline $\mathrm{X} 5$ & 0.76953 & 0.06909 & -0.23732 & -0.06079 & 5.30863 & 0.34741 \\
\hline $\mathrm{X} 6$ & 1.8932 & 0.65738 & 0.93256 & 0.06539 & -8.29622 & -0.30293 \\
\hline $\mathrm{X} 7$ & -0.00889 & 0.38946 & 0.07021 & -0.70767 & -1.93227 & 0.14814 \\
\hline $\mathrm{X} 8$ & -1.48486 & -0.57055 & 1.91469 & 0.61804 & 14.59406 & 1.55237 \\
\hline $\mathrm{X} 9$ & -0.11972 & -0.74341 & -2.17494 & 1.36955 & 1.39645 & 1.5111 \\
\hline Basis $\left(b_{i}\right)$ & 0.85489 & -0.06863 & -0.09487 & -0.26524 & -2.78596 & 0.82888 \\
\hline
\end{tabular}


Table (1) continue.

\begin{tabular}{|c|c|c|c|c|c|c|}
\hline Inputs & $\mathrm{W}_{19 \mathrm{j}}$ & $\mathrm{W}_{20 \mathrm{j}}$ & $\mathrm{W}_{21 \mathrm{j}}$ & $\mathrm{W}_{22 \mathrm{j}}$ & $\mathrm{W}_{23 \mathrm{j}}$ & $\mathrm{W}_{24 \mathrm{j}}$ \\
\hline $\mathrm{X} 1$ & -0.00371 & -3.51617 & -0.36589 & 1.78558 & 0.19317 & 0.16359 \\
\hline $\mathrm{X} 2$ & -1.72182 & -2.20865 & -1.93524 & -1.67427 & -0.31931 & -0.1789 \\
\hline $\mathrm{X} 3$ & -0.3105 & -1.31165 & -2.15559 & -2.46662 & -0.25848 & -0.44366 \\
\hline $\mathrm{X} 4$ & -2.77389 & -2.24697 & -0.90876 & -1.91466 & 0.14647 & 0.03132 \\
\hline $\mathrm{X} 5$ & -1.84264 & 4.79743 & 4.55436 & 4.35832 & -0.08961 & -0.21534 \\
\hline $\mathrm{X} 6$ & 3.97886 & -0.26087 & -1.09388 & -11.6051 & 0.03291 & -0.04524 \\
\hline $\mathrm{X} 7$ & 0.59902 & -1.82853 & -2.67285 & 4.2073 & -0.42139 & -0.32806 \\
\hline $\mathrm{X} 8$ & -1.61755 & -1.25338 & -0.42203 & -0.70279 & -0.27805 & 0.2651 \\
\hline $\mathrm{X} 9$ & -3.06923 & -1.3406 & 4.84537 & 2.07136 & -0.51104 & -0.39296 \\
\hline Basis $\left(b_{i}\right)$ & 1.39987 & 3.8611 & 1.94293 & 1.04252 & 0.52423 & 0.20113 \\
\hline
\end{tabular}

Table (1) continue.

\begin{tabular}{|c|c|c|c|c|c|c|}
\hline Inputs & $\mathrm{W}_{25 \mathrm{j}}$ & $\mathrm{W}_{26 \mathrm{j}}$ & $\mathrm{W}_{27 \mathrm{j}}$ & $\mathrm{W}_{28 \mathrm{j}}$ & $\mathrm{W}_{29 \mathrm{j}}$ & $\mathrm{W}_{30 \mathrm{j}}$ \\
\hline $\mathrm{X} 1$ & 1.34187 & -0.08706 & -0.31426 & 0.11654 & 0.29089 & 0.87729 \\
\hline $\mathrm{X} 2$ & 1.71035 & 1.17914 & -0.36778 & 0.21117 & -0.67129 & -0.26943 \\
\hline $\mathrm{X} 3$ & 0.47329 & -0.92997 & -0.87548 & 0.28102 & -0.16173 & -1.85397 \\
\hline $\mathrm{X} 4$ & 2.78154 & -1.40862 & -0.04305 & 0.02212 & -0.84651 & 1.8802 \\
\hline $\mathrm{X} 5$ & 2.6222 & 0.32806 & -0.18932 & 0.5289 & -1.29037 & -1.89565 \\
\hline $\mathrm{X} 6$ & -3.0136 & 0.82891 & 0.69578 & -0.12965 & 2.20423 & 2.60764 \\
\hline $\mathrm{X} 7$ & -3.37846 & -0.19147 & 0.35165 & -0.2092 & -0.02916 & 1.40695 \\
\hline $\mathrm{X} 8$ & 0.13597 & -0.61914 & -0.04826 & -0.18149 & -0.39168 & 1.61195 \\
\hline $\mathrm{X} 9$ & 2.33001 & -0.11619 & -0.9047 & 1.2018 & -1.34934 & -0.75101 \\
\hline Basis $\left(b_{i}\right)$ & -1.9734 & 0.20514 & 0.81245 & -0.10465 & 0.42771 & 0.29716 \\
\hline
\end{tabular}

Where engine power $(\mathrm{kW})$ was calculated from fuel consumption using the following relationship (Embaby, 1985),

Engine power $(k W)=\frac{Q_{P} \times \rho_{f} \times L C V \times \eta_{t h} \times \eta_{m}}{3600}=3.433 \times Q_{P}($ lit $/ \mathrm{h})$

$\rho_{f}=\quad$ Density of fuel, $\mathrm{kg} / \mathrm{lit}$ (for diesel fuel $=0.85 \mathrm{~kg} / \mathrm{lit}$ ) as reported by Hassann et al. (2009).

$\eta_{t h}=$ Thermal efficiency of the engine, (considered to be about $40 \%$ for diesel engine) as reported by Hassann et al. (2009).

$\eta_{m}=$ Mechanical efficiency of the engine, (considered to be about 
$80 \%$ for diesel engine) as reported by Hassann et al. (2009).

$\mathrm{LCV}=$ Lower calorific value of fuel, $\mathrm{kJ} / \mathrm{kg}$, (average LCV for diesel fuel is $45434 \mathrm{~kJ} / \mathrm{kg}$ ).

$3600=$ Units constant.

\subsubsection{Theoretical field capacity}

The theoretical field capacity of an implement is the rate of field coverage that would be obtained when the machine is performing its function using hundred percent of the time at the rated forward speed and always covering hundred percent of the rated width (Kepner et al., 1978). The theoretical field capacity (TFC, ha/h) was calculated using the following relationship (Culpin, 1976),

$$
\text { TFC }(h a / h)=\frac{W \times S}{10} \text {. }
$$

Where $S$ is plowing speed $(\mathrm{km} / \mathrm{h})$ and $W(\mathrm{~m})$ is chisel plow width which could be calculated as following:

$W(m)=\frac{N \times B}{2 \times 100}$

Where $\mathrm{N}$ is the number of chisel shares and $\mathrm{B}$ is horizontal distance between two adjacent shares in one row $(\mathrm{cm})$.

\subsubsection{Field efficiency}

The field efficiency $\left(F_{E}, \%\right)$ was calculated using the following relationship (Kumar et al., 2013), $F_{E}(\%)=\frac{A F C}{T F C} \times 100$

\subsubsection{Draft and drawbar power requirement}

To obtain the required draft, assume value of (loading factor, $\mathrm{X}$, decimal), however, $\mathrm{X}$ is calculated from the following formula (Ismail and Burkhardt, 1993),

$X($ decimal $)=\frac{E_{P T O}}{A_{P T O}}$

Where $E_{\text {РTO }}$ is the implement equivalent power take-off and $A_{\text {РTO }}$ is the tractor available take-off power. $E_{\text {РTO }}$ was calculated using the drawbar power $\left(D_{B P}\right)$ and tractive efficiency $(T E)$. However, the tractive efficiency was taken from Table (2) based on tractor type and soil 
condition. $E_{\text {РТО }}$ could be calculated from Ismail and Burkhardt (1993) and Akinnuli et al. (2014) as follows:

$$
\begin{aligned}
E_{\text {PTO }} & =\frac{D_{B P}}{0.96 \times T E} \ldots \ldots . \\
E_{\text {PTO }} & =\frac{D_{F} \times S}{0.96 \times T E \times 3.6} .
\end{aligned}
$$

Where TE is tractive efficiency (decimal), $D_{B P}$ is drawbar power $(\mathrm{kW})$, $D_{F}$ is implement draft $(\mathrm{kN})$ and $\mathrm{S}$ is plowing forward speed $(\mathrm{km} / \mathrm{h})$ and 3.6 is conversion factor. Also, $A_{P T O}$ could be calculated as follows (Zoz and Grisso, 2003):

$A_{\text {PTO }}=T_{\text {Power }} \times 0.83$

Where $T_{\text {Power }}$ is tractor power, so, Eq. (28) could be rewrite as follows:

$X($ decimal $)=\frac{D_{F} \times S}{0.96 \times T E \times 3.6 \times T_{\text {Power }} \times 0.83}$

Thus, by rewrite Eq. (32), the draft could be calculated as follows:

$D_{F}=\frac{X(\text { decimal }) \times 0.96 \times T E \times 3.6 \times T_{\text {Power }} \times 0.83}{S}$

$D_{B P}=\frac{D_{F} \times S}{3.6}$

Where $D_{B P}$ is drawbar power $(\mathrm{kW})$.

Table (2). Tractive efficiency (TE, decimal) corresponding to soil type and tractor type.

\begin{tabular}{|l|c|c|c|}
\hline \multirow{2}{*}{ Soil condition } & \multicolumn{3}{|c|}{ Tractor type } \\
\cline { 2 - 4 } & 2WD & FWA & 4WD \\
\hline Firm soil & 0.72 & 0.77 & 0.78 \\
\hline Tilled soil & 0.67 & 0.73 & 0.75 \\
\hline Sandy or soft soil & 0.55 & 0.65 & 0.78 \\
\hline
\end{tabular}

Source: ASABE (2000).

Specific fuel consumption for tillage process $\left(S F C_{P}\right.$ lit/kW.h) could be calculated from fuel consumption estimated by C-Sharp application as follows. 


$$
S F C_{P}=\frac{Q_{P}}{D_{B P}}
$$

Also, standard specific fuel consumption $\left(S F C_{A S A B E}\right.$, lit/kWh) could be estimated from ASABE (2000) above 20\% load for diesel type of fuel, however, specific fuel consumption for diesel engines typically ranges from 0.244 to $0.57 \mathrm{lit} / \mathrm{kWh}$ and affects by percent load on the engine (Omid, 2006). The following relationship is for estimating specific fuel consumption $\left(S F C_{A S A B E}\right.$, lit/kWh) according to ASABE (2000),

$S F C_{A S A B E}=2.64 \times X+3.91-0.203 \sqrt{738 \times X+173}$.

To estimate the required draft of a chisel plow, $X$ is changed starting of 0.01 using the loop as illustrated in Figure (2) inside the C-Sharp application until $S F C_{P}=S F C_{A S A B E}$ however, the new value of $\left(D_{F}, \mathrm{kN}\right)$ was obtained from the final value of $\mathrm{X}$ after $S F C_{P}=S F C_{A S A B E}$ and the required draft could be obtained using the following relationship,

$D_{F}=\frac{X(\text { decimal }) \times 0.96 \times T E \times 3.6 \times T_{\text {Power }} \times 0.83}{S}$.

The final drawbar power or draft power is calculated from the following relationship,

$D_{B P}=\frac{\text { Final value of } D_{F} \times S}{3.6}$

In the case of $S F C_{P} \neq S F C_{A S A B E}$, or $\mathrm{X}=0.99$, the draft could be obtained as follows:

$$
\text { Draft }=\frac{T_{\text {Power }} \times 0.83 \times 3.6}{S \times S F \times 1.25}
$$

Where SF is soil factor (Yousif, et al., 2013) and could be obtained from Edwards (2007) as shown in Table (3).

Table (3). Soil factor (SF) corresponding to soil type and tractor type.

\begin{tabular}{|l|c|c|c|}
\hline \multirow{2}{*}{\multicolumn{1}{|c|}{ Soil condition }} & \multicolumn{3}{|c|}{ Tractor type } \\
\cline { 2 - 4 } & 2WD & FWA & 4WD \\
\hline Firm soil (untilled soil) & 1.64 & 1.54 & 1.52 \\
\hline Tilled soil & 1.75 & 1.61 & 1.56 \\
\hline Sandy or soft soil & 2.13 & 1.82 & 1.67 \\
\hline
\end{tabular}




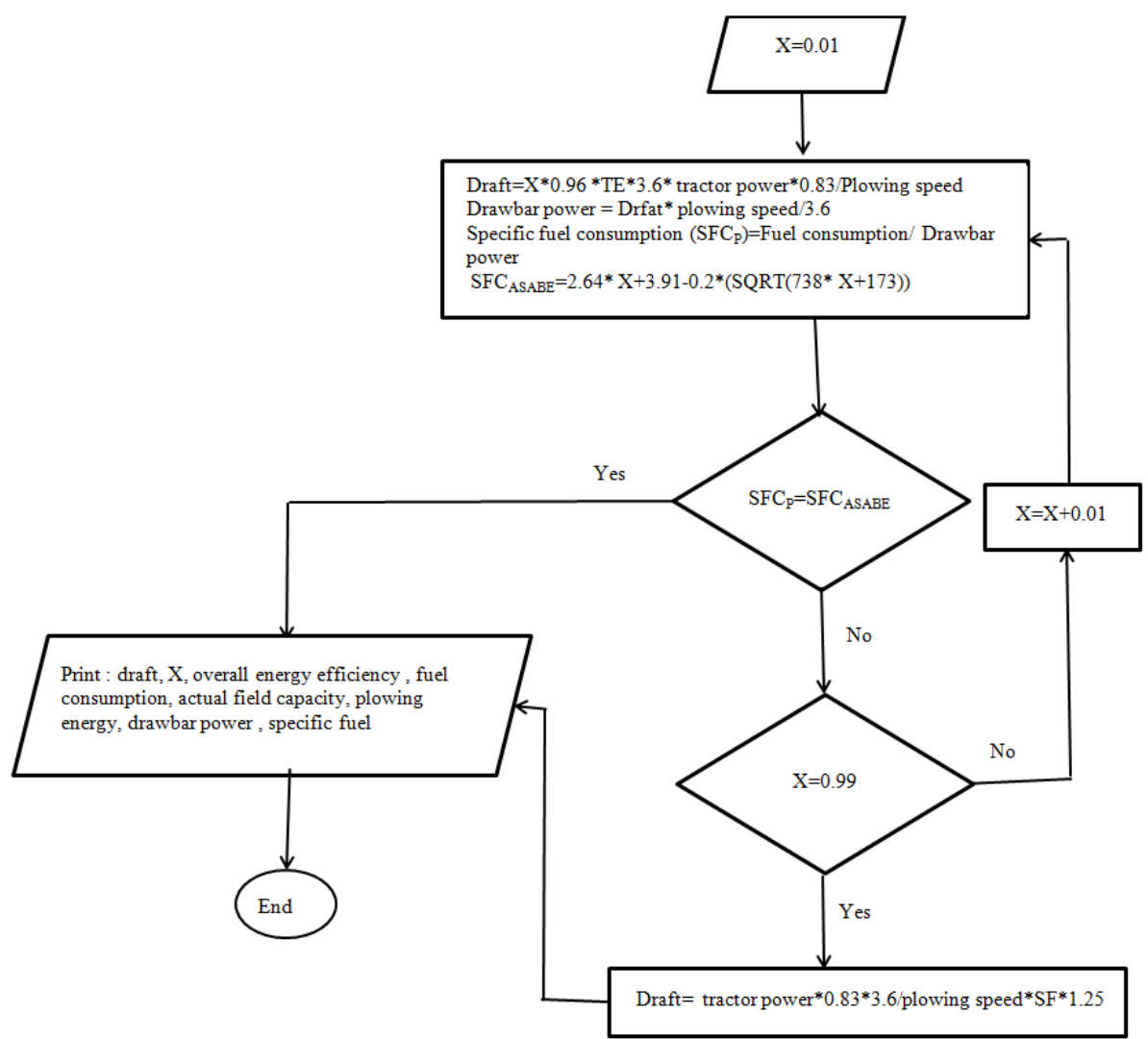

Figure (2). Loop to estimate $S F C_{P}$ and $S F C_{A S A B E}$ by changing value of $\mathbf{X}$.

\subsubsection{Unit draft}

There are different forms of to represent draft requirements of a chisel plow. However, the two famous forms to represent draft requirements of a chisel plow are as follows (Al-Suhaibani and Ghaly, 2013; Ndisya et al., 2016):

Unit draft per implement width $(N / m)=\frac{\operatorname{Draft}(N)}{\text { implement width }(m)}$

Unit draft per plowing area $\left(\mathrm{N} / \mathrm{cm}^{2}\right)=\frac{\operatorname{Draft}(\mathrm{N})}{\text { implement width }(\mathrm{cm}) \times \text { plowing depth }(\mathrm{cm})}$

\subsubsection{Overall energy efficiency}

Overall energy efficiency was determined according to the equation appeared in Crowell and Bowers (1985).

$\operatorname{OEE}(\%)=\frac{D_{B P}}{P_{f}} \times 100$ 
Where OEE is overall energy efficiency (\%) and $P_{f}$ is fuel equivalent power $(\mathrm{kW})$ and it could be calculated as follows:

$$
P_{f}(\mathrm{~kW})=\frac{Q_{P}(\mathrm{lit} / \mathrm{h}) \times 45434(\mathrm{~kJ} / \mathrm{kg}) \times 0.85(\mathrm{~kg} / \mathrm{lit})}{3600}=10.727 \times Q_{P}(\mathrm{lit} / \mathrm{h}) \ldots(43
$$

Ranjbarian et al. (2015) used value of 10.2 as a conversion unit in their equation for calculating OEE. However, Crowell and Bowers (1985) reported that the normal range for overall energy efficiency is 10-20\%. A tractor-implement combination having an overall energy efficiency below $10 \%$ indicates poor load matching or/and low tractive efficiency, while a value above $20 \%$ indicates a good load match or/and high tractive efficiency.

\subsection{C-Sharp application description}

The C-Sharp application was written in C-Sharp programming language to determination of actual field capacity (ha/h) and fuel consumption per unit area (lit/ha) of a tractor-chisel plow system. The required equations were formulated using the obtained weights from a trained artificial neural network model that trained using actual data from field experiments. In C-Sharp application, determination of actual field capacity (ha/h) and fuel consumption per unit area (lit/ha) of a tractorchisel plow system is associated with tractor power, plow width, plowing depth, plowing speed, initial soil moisture content, initial soil bulk density, sand percentage, silt percentage and clay percentage. Tractor loading factor was the main issue in the present application as it was used as a controller for determination of the required draft by comparing both specific fuel consumption calculated by the application and specific fuel consumption calculated using the equation of ASABE standard (ASABE, 2000). Overall energy efficiency in the range of 10-20\% was acted to select the values of the optimum affecting parameters that match the pull provided by a tractor with the draft requirement of a chisel plow. The application displays some performance parameters of a tractor-chisel plow system such as drawbar power, total implement draft, field efficiency and fuel consumption.

\subsection{Field experiment data for validation of C-Sharp application results}

For validation of the developed C-Sharp application, field experiment was conducted using chisel plow ( 7 shares) and the horizontal distance 
between the adjacent two shares was $50 \mathrm{~cm}$, so, the plow width was 175 $\mathrm{cm}$. The experiment was conducted in loamy sand soil in private farm located at Riyadh region, Saudi Arabia. The latitude of the experiment site was $24.23^{\circ} \mathrm{N}$, longitude was $47.65{ }^{\circ} \mathrm{E}$ and Altitude was $396.36 \mathrm{~m}$. The arrangements for leveling the chisel plow were made. Four soil samples were gathered by an auger to depth of $25 \mathrm{~cm}$. The experiment purpose was to determine actual field capacity, fuel consumption and draft.

Soil moisture content was determined by the standard oven method by drying soil samples in electric oven at $105^{\circ} \mathrm{C}$ for 24 hours and soil moisture content was determined based on dry base (Black et al., 1965) as averaged of four samples. Average soil bulk density is also determined according to Black et al. (1965). Moreover, soil cone index was measured by a hand digital penetrometer (Figure 3). The model of penetrometer is SC900 soil compaction meter from field Scout. It could be connected to the computer to retrieve the stored cone index and the related depth. The readings were taken up to $17 \mathrm{~cm}$. Mean characteristics of the soil in the experiment site are shown in Table (4).

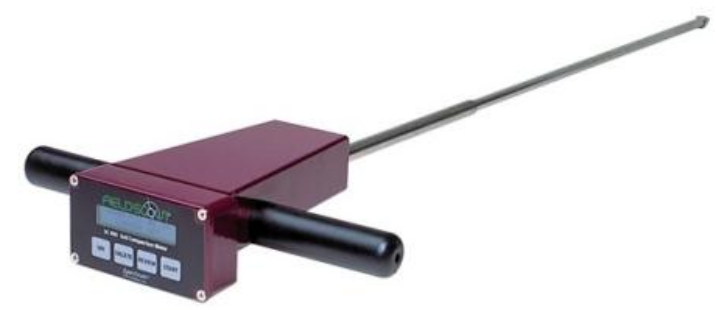

Figure (3). Hand digital penetrometer for measuring soil cone index.

Table (4). Mean characteristics of the soil in the experimental site.

\begin{tabular}{|l|c|c|}
\hline \multicolumn{1}{|c|}{ Soil parameters } & Value & Unite \\
\hline Sand & 75.6 & $\%$ \\
\hline Silt & 12.4 & $\%$ \\
\hline Clay & 12 & $\%$ \\
\hline Soil texture & Loamy sand & $(---)$ \\
\hline Soil moisture content & 10.06 & $\%, \mathrm{db}$ \\
\hline Soil bulk density & 1.53 & $\mathrm{~g} / \mathrm{cm}^{3}$ \\
\hline Soil cone index & 847.2 & $\mathrm{kPa}$ \\
\hline
\end{tabular}


The fuel consumption (lit/ha) was measured by refilling the fuel tank after plowing plot specific area and at the same time, draft measurements and the time required for plowing the plot area were recorded. Plowing depth was measured as the vertical distance from the top of the undisturbed soil surface to the plow's deepest penetration. In this work, the plowing depth was $25 \mathrm{~cm}$. The horizontal force (draft) was measured using a load cell (model Omega with a capacity of 0-10000 lb) using the method described in (PAES, 2001). The plowing speed was $3 \mathrm{~km} / \mathrm{h}$. The plow was passed one time on the soil. An experimental block about $60 \mathrm{~m}$ long by $4 \mathrm{~m}$ wide was utilized during experiments. A small block of approximately $15 \mathrm{~m}$ long by $4 \mathrm{~m}$ wide, in the beginning of each tested block, was used to enable the tractor and chisel plow to reach a steady state condition of the required plowing speed and plowing depth. The chisel plow was hitched to Kubota L4400 tractor (gross engine power was $33.8 \mathrm{~kW}$, net engine power was $32.1 \mathrm{~kW}$ and PTO power was $28 \mathrm{~kW}$ ) as shown in Figure (4) and the other tractor was New Holland 100-90 (FWA) tractor with power of $74.6 \mathrm{~kW}$. The draft was recorded within the distance of $50 \mathrm{~m}$. The plowing speed was calculated by measuring of distance of five turns of the tractor rear wheel with time. On the same field, the plow was lifted out the ground and the rear tractor was pulled to record the idle draft force. The difference gave the draft requirement of the chisel plow. The actual field capacity was calculated according to the following equation:

Actual field capacity $(h a / h)=\frac{\left(A_{P}, m^{2}\right) \times(3600, s / h)}{(T P, s) \times\left(10000, m^{2} / h a\right)}$.

Where $A_{p}$ is the plot area (width $\times$ length, $\mathrm{m}^{2}$ ), TP is the time required for plowing plot area (s). However, fuel consumption (lit/ha) was calculated as follows:

Fuel consumption per unit area $($ lit/ha $)=\frac{\left(Q_{\text {Diesel }}, \mathrm{cm}^{3}\right) \times\left(10000, \mathrm{~m}^{2} / \mathrm{ha}\right)}{\left(A_{P}, \mathrm{~m}^{2}\right) \times\left(1000, \mathrm{~cm}^{3} / \mathrm{lit}\right)} \ldots . .(45)$

Where $Q_{\text {Diesel }}$ in $\mathrm{cm}^{3}$ is the amount of consumed fuel during plowing $\mathrm{A}_{\mathrm{p}}$ area. 


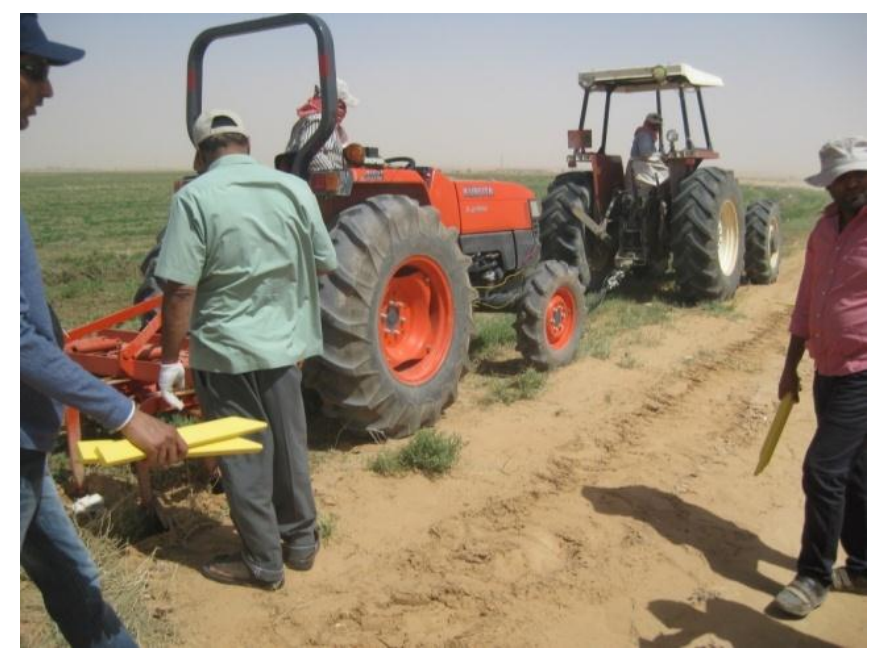

Figure (4). Measuring of draft requirement of chisel plow -tractor system.

\section{RESULTS AND DISCUSSION}

\subsection{General}

Most of the previous computer programs (Eldoma, 2008; Al-Hamed et al., 2010; Ishola et al., 2010; Mohamed et al., 2011) of the prediction of performance of a tractor-tillage implement system were employed draft equation developed by ASABE Standard D497.5 (ASABE, 2006). This draft equation is as follows:

$D_{f}=F_{i}\left[A+B(S)+C(S)^{2}\right] \times W \times d$

Where $D_{f}=$ Implement draft $(\mathrm{N}), F_{i}=$ Dimensionless and it used for soil texture adjustment parameter $\mathrm{i}=1$ for fine; 2 for medium and 3 for coarse soil, A, B and C = machine specific parameters, $\mathrm{S}=$ Field speed $(\mathrm{km} / \mathrm{h}), \mathrm{W}$ $=$ Width of the implement $(\mathrm{m})$ and $\mathrm{d}=$ Plowing depth $(\mathrm{cm})$. As shown in Eq. (46), every developed computer programs for the prediction of performance of a tractor-tillage implement system used the same constants for calculating draft of the tillage implements. Due to draft requirement of tillage implements is depended on soil texture and soil properties (Jafari et al., 2011), thus actual field experiments have to execute to gather such draft data under various soil conditions (Manuwa and Ogunlami, 2010). Accordingly, one of the settlements of the developed C-Sharp application is depended on actual field experimental data for obtaining the constants of the required equations. 


\subsection{C-Sharp application performance}

The application was implemented in C-Sharp programming environment for use in different purposes such as educational and research needs. CSharp offers a flexible, object-oriented, user friendly language which is focused on user and his interaction with the program. The developed application is aimed to predict the field performance indicators of a tractorchisel plow system. The application comprises three windows that serve specific purposes in the development process. After building the application, it was converted to a free-standing executable version in order to run the application directly on the Windows desktop, without starting up the C-Sharp environment. The application could be edited and/or updated to predict performance indicators of other tractor-tillage implement systems.

The application starts with about window (Figure 5), then move to input variable window (Figure 6) and ends with the final result required by the user. In addition, user can select chart to show the relationship between specific fuel consumption and loading factor with all iterations until intersection of both specific fuel consumption based on ASABE equation and calculated specific fuel consumption as shown in Figure (7). The application confirms that all entered values for different variable are in the specific range as shown in Table (5) that specified in the application.

\section{Table (5). The range of inputs variables in C-Sharp application.}

\begin{tabular}{|l|c|}
\hline \multicolumn{1}{|c|}{ Inputs } & Range \\
\hline Plow width $(\mathrm{cm})$ & $100-300$ \\
\hline Tractor power $(\mathrm{kW})$ & $25-104$ \\
\hline Plowing depth $(\mathrm{cm})$ & $7-30$ \\
\hline Plowing speed $(\mathrm{km} / \mathrm{h})$ & $2-7$ \\
\hline Sand $(\%)$ & $11-80$ \\
\hline Silt $(\%)$ & $11-55$ \\
\hline Clay $(\%)$ & $9-53$ \\
\hline Soil moisture content $(\%, \mathrm{db})$ & $7-50$ \\
\hline Soil bulk density $\left(\mathrm{g} / \mathrm{cm}^{3}\right)$ & $1.2-1.8$ \\
\hline
\end{tabular}




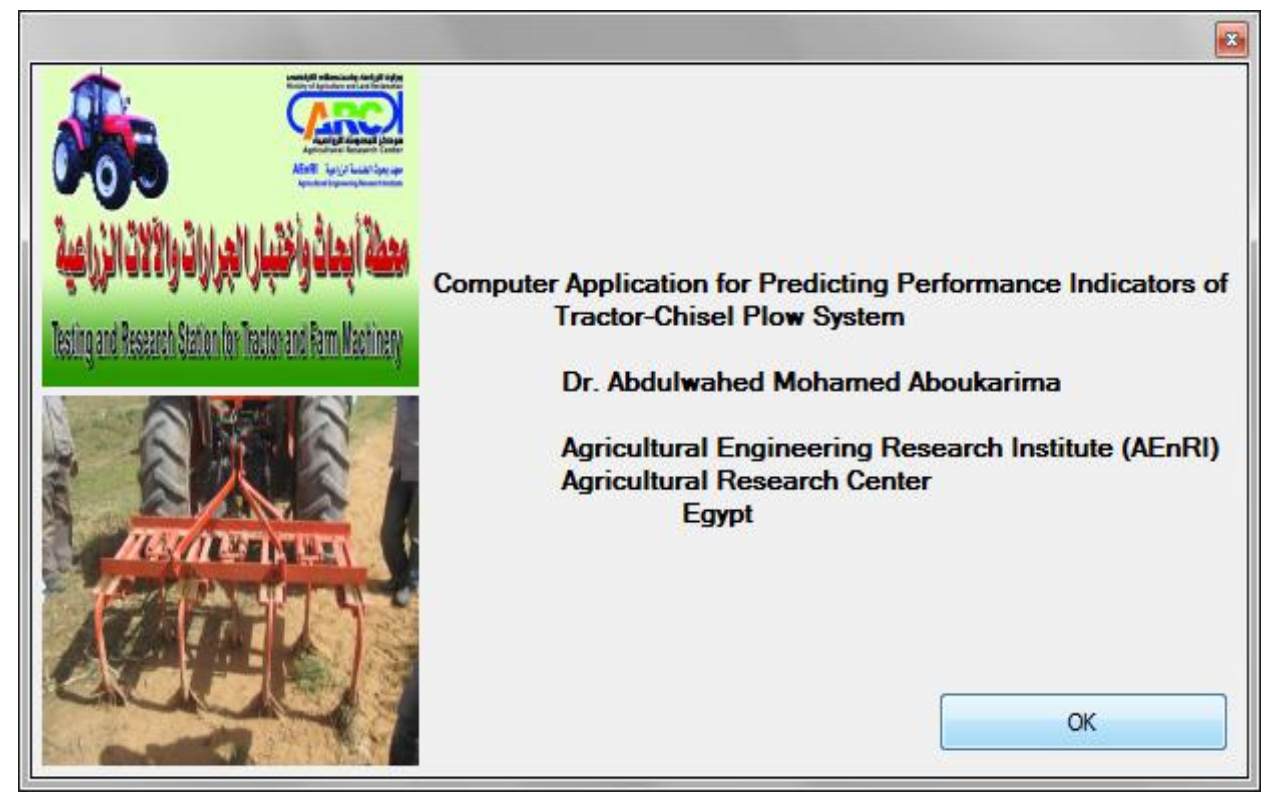

Figure (5).The C-Sharp application starts with about window.

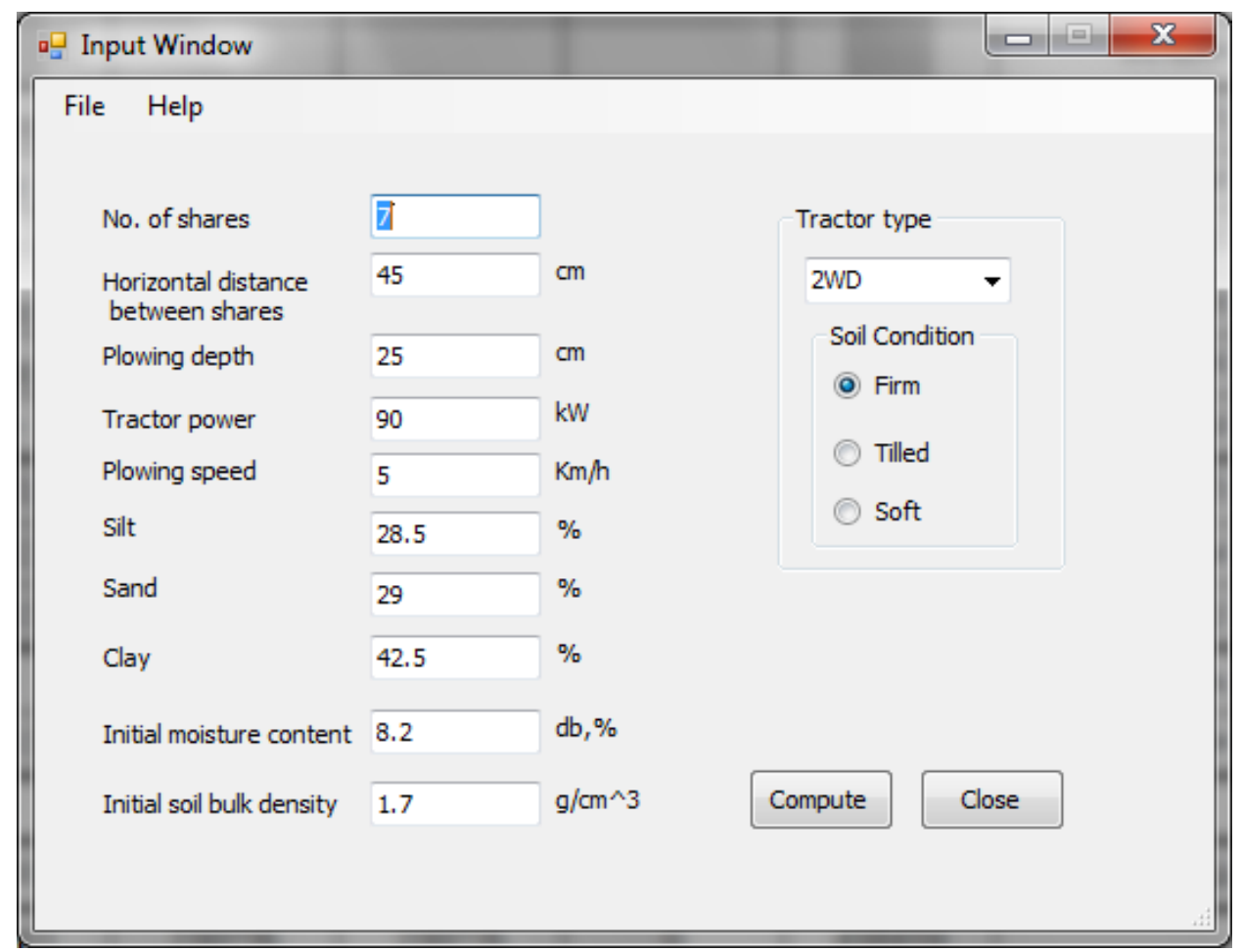

Figure (6). The inputs window. 


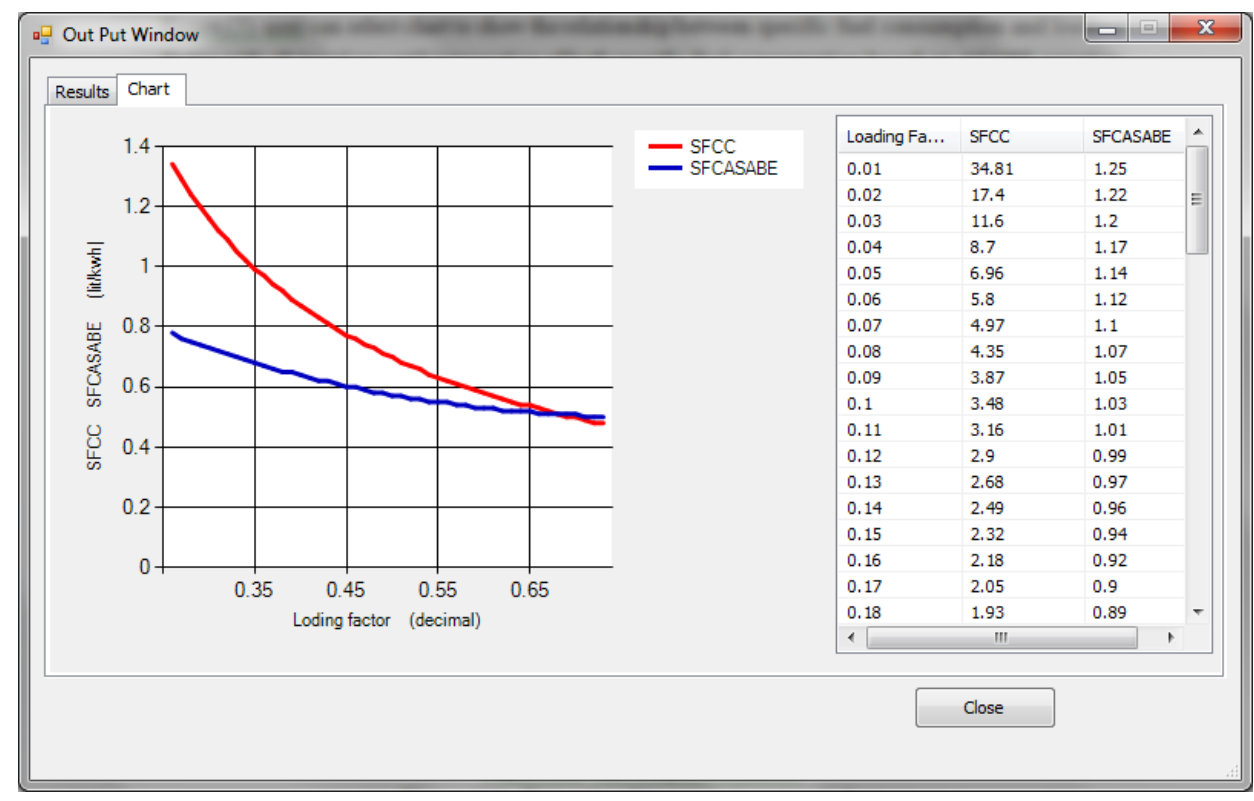

Figure (7).Online relationship between both calculated specific fuel consumption and specific fuel consumption based on ASABE and loading factor.

An alert message as shown in Figure (8) was displayed to the user if he entered input values out of the specific range. The output window (Figure 9) was classified to three performance indicators. The performance indicators I include:

- Theoretical field capacity (ha/h).

- Actual field capacity (ha/h).

- Field efficiency (\%).

- Fuel consumption per unit area (lit/ha).

- Fuel consumption (lit/h).

- Energy required based on fuel consumption (kWh/ha).

The performance indicators II include:

- Draft $(\mathrm{kN})$.

- Unit draft (draft per unit plow width, N/m).

- Unit draft (draft per unit plowing area, $\mathrm{N} / \mathrm{cm}^{2}$ ).

- Draft power $(\mathrm{kW})$.

- Energy required based on draft requirements $(\mathrm{kWh} / \mathrm{ha})$

The performance indicators III include:

- Loafing factor (decimal). 
- Calculated specific fuel consumption (lit/kWh).

- Specific fuel consumption based on ASABE equation (lit/kWh).

- Overall energy efficiency $(\%)$

Before running the application on the computer, user has to enter values of number of chisel shares and the horizontal distance between two adjacent shares in one row $(\mathrm{cm})$. The parameters of a tractor-chisel system data (tractor power, plowing speed, plowing depth) must entered by the user and the application is verified that they are in the appropriate range. The soil data (sand, silt and clay percentages, initial soil moisture content and initial soil bulk density) must entered by the user and the application is also verified that these parameters are in the appropriate range.

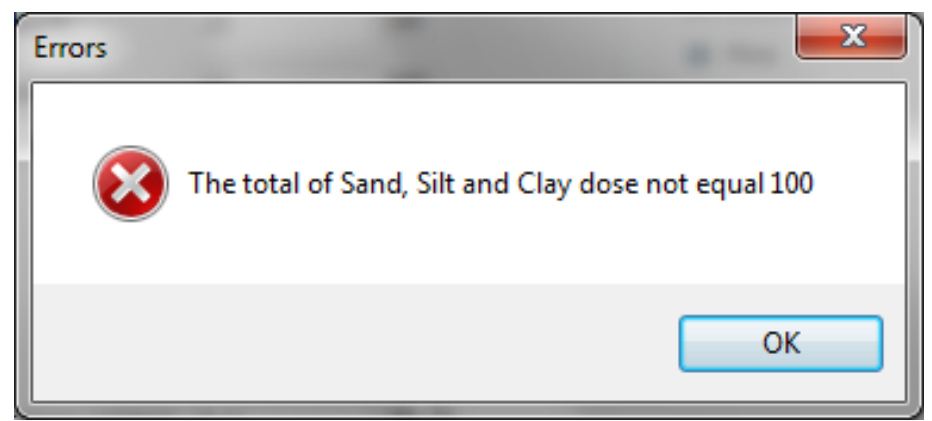

Figure (8). Alert message flag to re-enter values of input variables within the specific range.

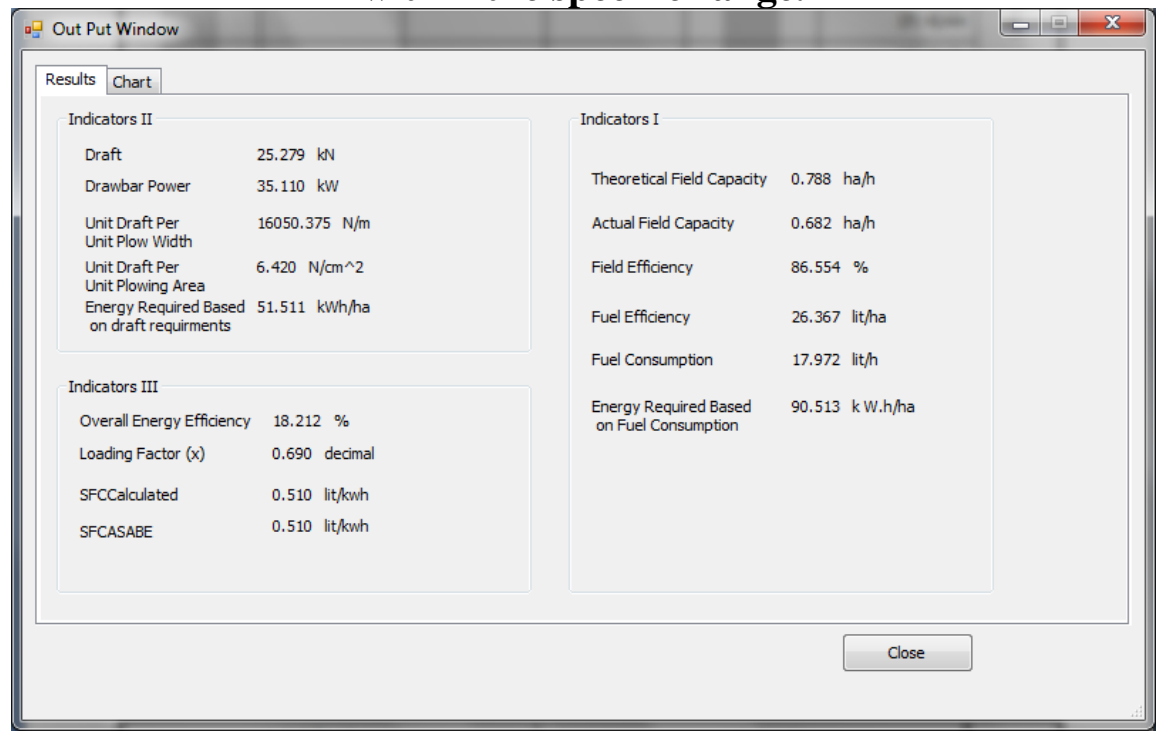

Figure (9). The outputs window. 


\subsection{Validation of C-Sharp application}

\subsubsection{Using experimental data from previous study}

To validate the developed C-Sharp application for estimation of draft of a chisel-plow-tractor unit, field experimental data are collected from Aboukarima (2007). These data are as follows: tractor power was 50 kW (FWA), soil condition was Firm, plowing speed was $4.8 \mathrm{~km} / \mathrm{h}$, plowing depth was $15 \mathrm{~cm}$, sand percentage was $18.12 \%$, clay percentage was $34.78 \%$ and silt percentage was $47.10 \%$. The chisel was 7 shares and the horizontal distance between two shares was $50 \mathrm{~cm}$, the initial soil moisture content was $15.40 \%(\mathrm{db})$ and the initial soil specific weight was $13.44 \mathrm{kN} / \mathrm{m}^{3}$ (initial soil bulk density was $1.366 \mathrm{~g} / \mathrm{cm}^{3}$ ). These values of the inputs are illustrated in Figure (10) and the outputs for such inputs are shown in Figure (11). It is clear that the simulated draft was $14.053 \mathrm{kN}$ after adjusting the loading factor to be 0.620 in the developed application, meanwhile, the actual draft from Aboukarima (2007) was $16.73 \mathrm{kN}$. The relative error was $(16.73-14.053) / 16.73 * 100=16 \%$.

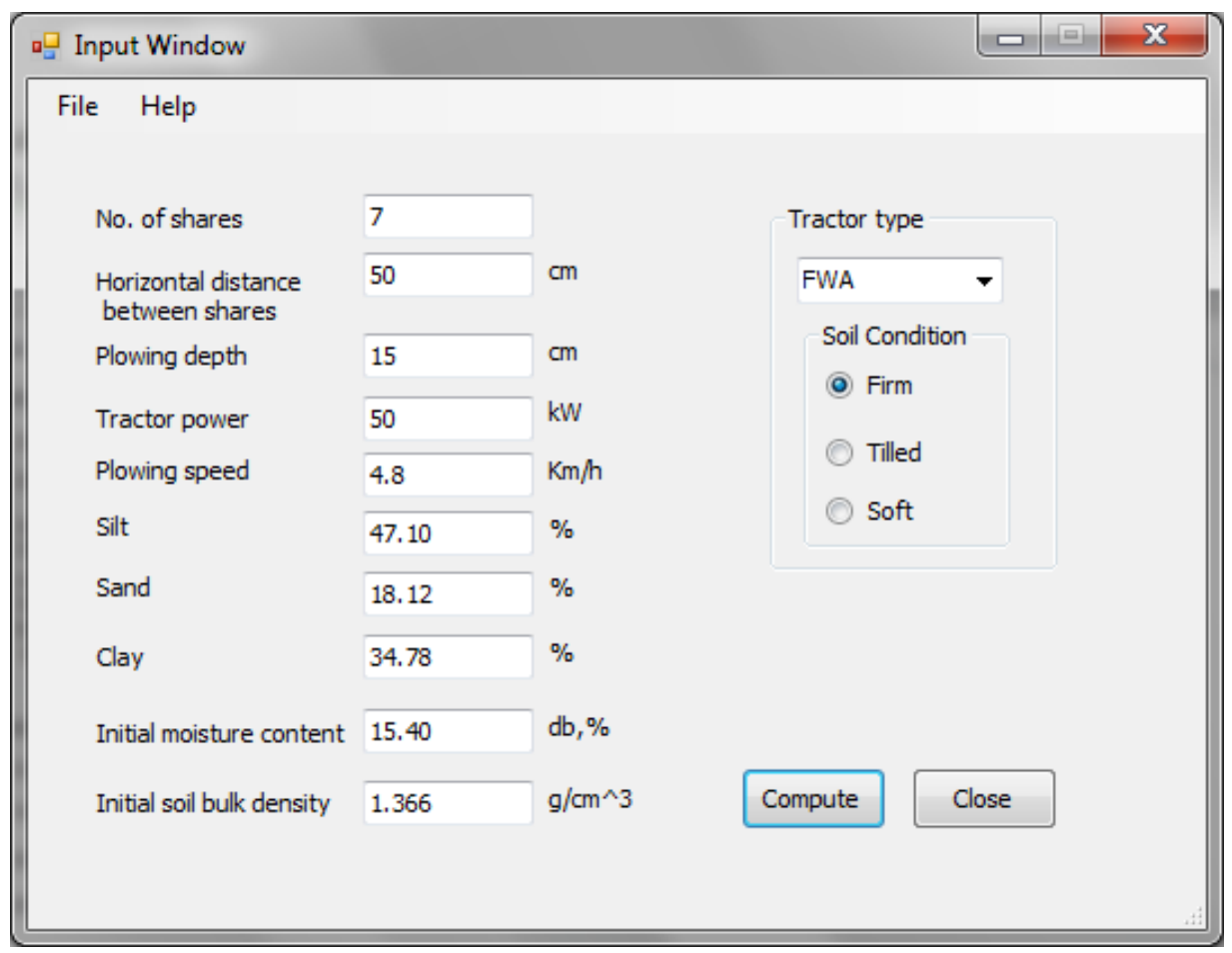

Figure (10). Input data from Aboukarima (2007) to validate the performance of the developed C-Sharp application. 


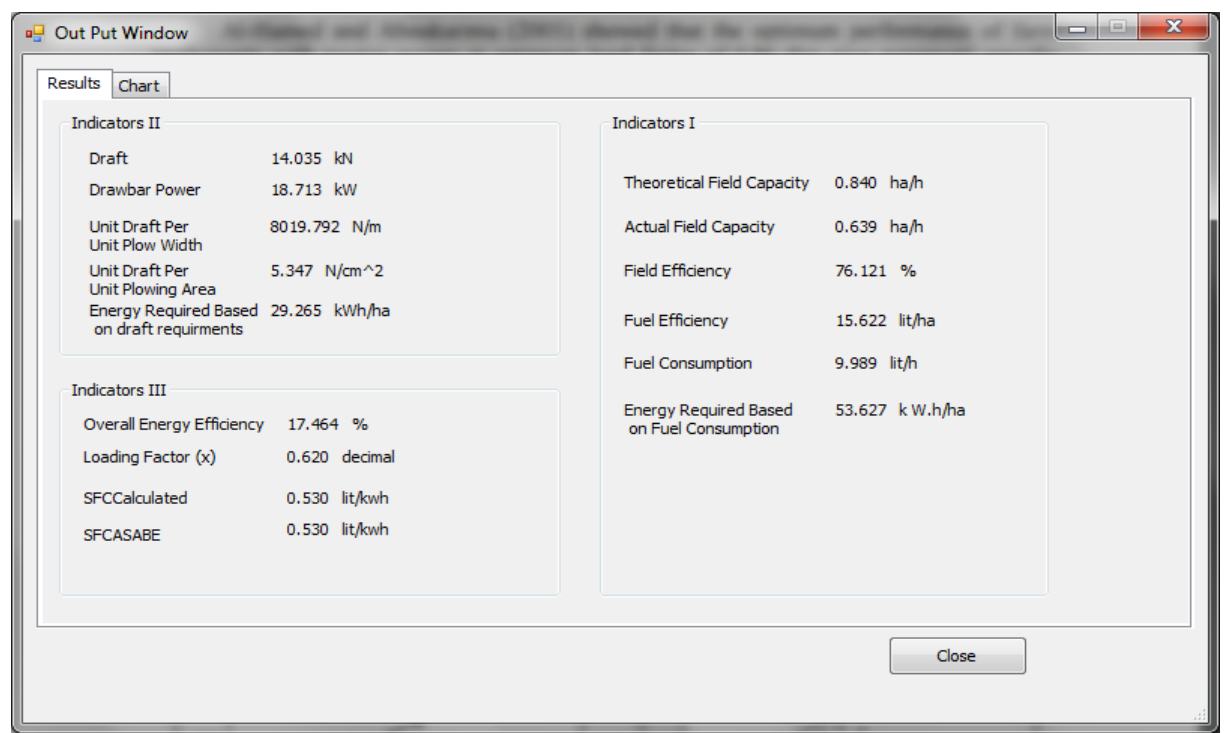

Figure (11). Output data from the developed C-Sharp application (the input data were taken from Aboukarima (2007) (fuel efficiency means fuel consumption per unit area (lit/ha).

\subsubsection{Using data from a field experiment}

The inputs of the data of the described experiment in section 2.5 are shown in Figure (12) and the outputs for plowing speed of $3 \mathrm{~km} / \mathrm{h}$ are shown in Figure (13). However, Table (6) illustrates actual and simulated actual field capacity, fuel consumption and draft. It is clear that the relative error was $27 \%$ for actual field capacity, and its values were $-21 \%$ and $-17 \%$ when simulated fuel consumption and draft, respectively using the developed C-Sharp application .

Table (6). Actual and simulated actual field capacity, fuel consumption and draft.

\begin{tabular}{|l|c|c|c|}
\hline Performance indicators & Item & Value & $\begin{array}{c}\text { Relative error } \\
(\%)^{*}\end{array}$ \\
\hline $\begin{array}{l}\text { Actual field capacity } \\
\text { (ha/h) }\end{array}$ & Actual & 0.362 & \multirow{2}{*}{27} \\
\cline { 2 - 3 } Fuel consumption (lit/h) & Simulated & 0.263 & \multirow{2}{*}{-21} \\
\cline { 2 - 3 } & Sctual & 7.25 & \multirow{2}{*}{-17} \\
\hline \multirow{2}{*}{ Draft $(\mathrm{kN})$} & Actual & 11.24 & \\
\cline { 2 - 3 } & Simulated & 13.182 & \\
\hline
\end{tabular}

* Relative error $=\left(\frac{\text { Actual }- \text { Simulated }}{\text { Actual }}\right) \times 100$ 


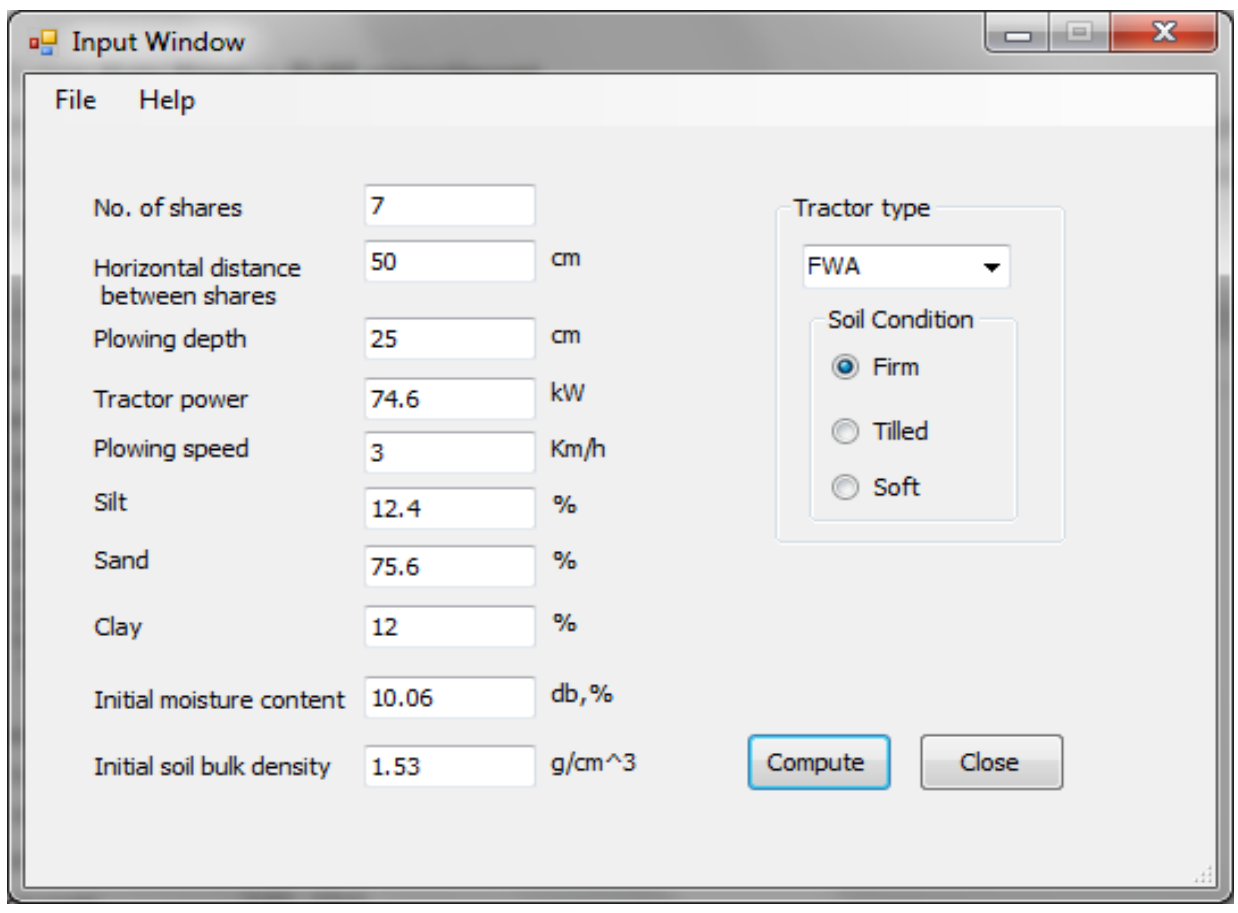

Figure (12). Input data from experimental work described in section 2.5 to validate the performance of the developed C-Sharp application.

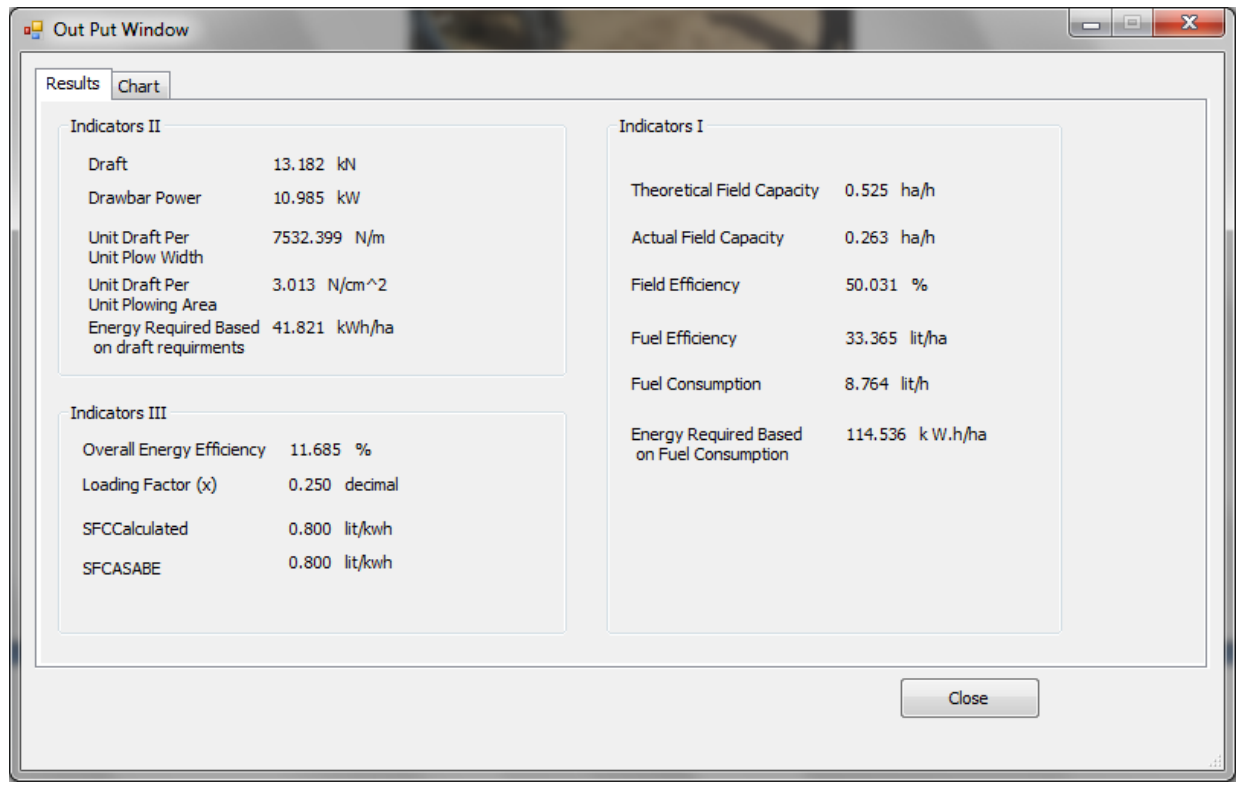

Figure (13). Output data from the developed C-Sharp application (the input data were taken from experimental work described in section 2.5) (fuel efficiency means fuel consumption per unit area, lit/ha). 


\subsection{Sensitivity analysis}

For sensitivity analysis, plowing speed was changed from 2 to $6 \mathrm{~km} / \mathrm{h}$ and the other parameters were fixed as follows: tractor power was set to be 90 $\mathrm{kW}$, sand percentage was set to be $29 \%$, silt percentage was set to be $28.5 \%$, clay percentage was set to be $42.5 \%$, initial soil bulk density was set to be $1.7 \mathrm{~g} / \mathrm{cm}^{3}$ and initial soil moisture content was set to be $8 \%, \mathrm{db}$, plowing depth was set to be $25 \mathrm{~cm}$, plow width was set to be $157.5 \mathrm{~cm}$, tractor type was set to be FWA and soil condition was set to be firm. However, Figure (14) shows the simulation results at varying plowing speed on actual field capacity, fuel consumption per unit area and fuel consumption per unit time. Meanwhile, Figure (15) shows the simulation results when varying plowing speed vs. loading factor, overall energy efficiency (OEE) and specific fuel consumption. It is clear from Figure (14) that increasing plowing speed result to increasing simulated actual field capacity and this finding is agreed with the findings by (Hamod and Essa, 2010; Meselhy, 2014; Zaied et al., 2014; AL-Mafrachi, 2015). Also, it is clear from Figure (14) that increasing plowing speed result to decreasing simulated fuel consumption per unit area and increasing fuel consumption per unit time and this finding is agreed with the results of AL-Mafrachi (2015).

AL-Mafrachi (2015) indicted that increasing plowing speed from 2.35 to 4.25 then to $6.5 \mathrm{~km} / \mathrm{h}$ result to decreasing fuel consumption per unit area from 6.832 to 5.736 then to $4.195 \mathrm{lit} /$ Donam (in Iraq 1 Donam $=2500 \mathrm{~m}^{2}$ ) during plowing with chisel plow that because increasing speed tractor means using engine power perfectly and reduced the time required for operation and that result to increasing effective field capacity and that result also decreasing fuel consumption in one Donam. Moreover, ALMafrachi (2015) indicated that increasing plowing speed from 2.35 to 4.25 then to $6.5 \mathrm{~km} / \mathrm{h}$ result to increasing fuel consumption per unit time from 6.602 to 9.662 then to $10.533 \mathrm{lit} / \mathrm{h}$. It is clear from Figure (15) that the lowest specific fuel consumption was obtained at plowing speed of 6 $\mathrm{km} / \mathrm{h}$ and the highest overall energy efficiency was also obtained at the same plowing speed that means the mechanization unit utilized the engine power perfectly. 

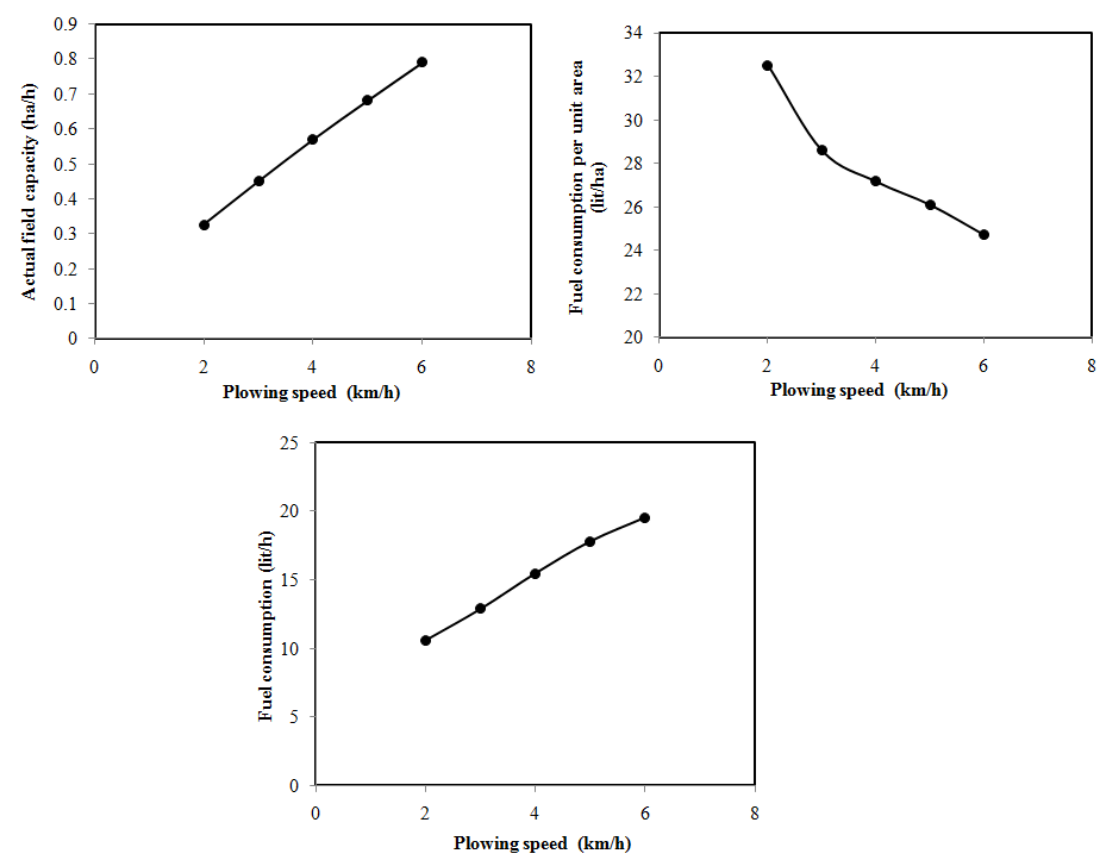

Figure (14). Effect of plowing speed on actual field capacity, fuel consumption per unit area and fuel consumption per unit hour.
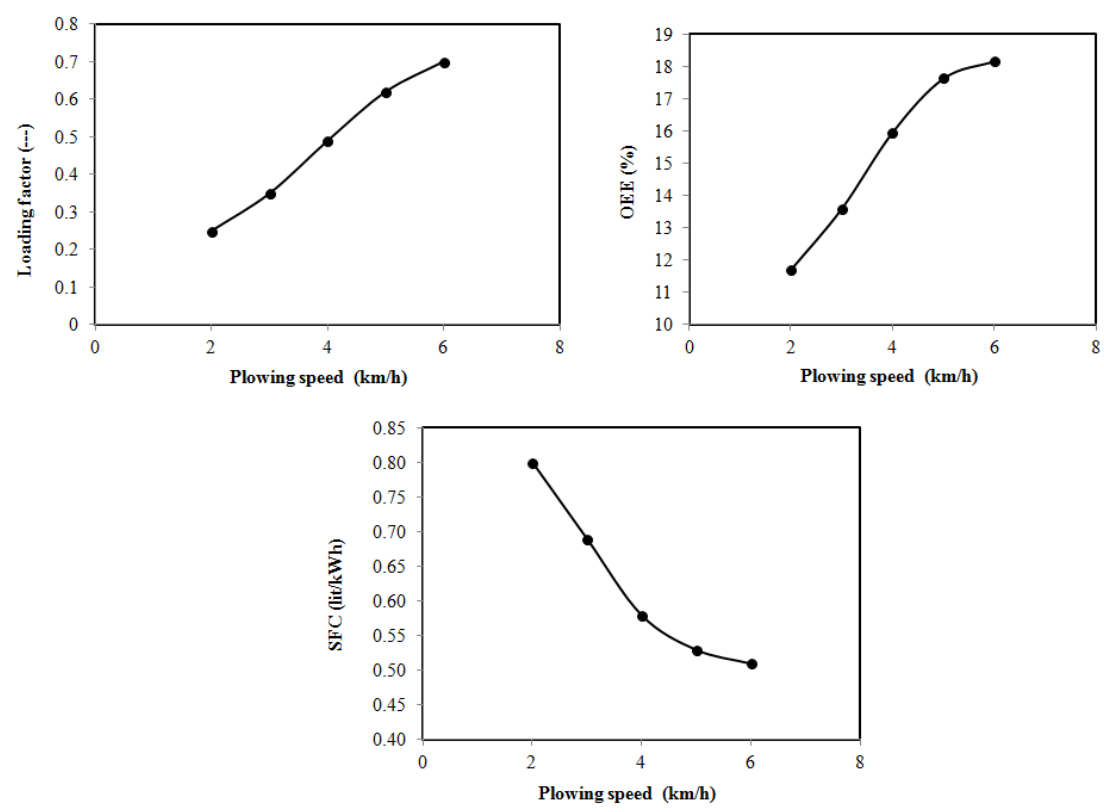

Figure (15). Effect of plowing speed on loading factor, overall energy efficiency (OEE) and specific fuel consumption. 


\section{CONCLUSION}

C-Sharp computer application that can be used to predict a tractor- chisel plow system performance indicators was developed. It could be used for farm machinery management, educational and research purposes. The application could find the optimum operational parameters for a given tractor and chisel plow combination. The visual programming environment used to develop the application makes it relatively flexible and easy to use. It is user friendly and could be run on any Windows desktop without C-Sharp environment. The major equations inside the application could be editing or updated and manipulated to suit prediction of performance indicators of other tractor-tillage implement systems. The developed application was tested with data from pervious study and actual experimental data and for draft simulation, the relative error was $16 \%$ for data from a previous study and it was $-17 \%$. The developed application was found to be sensitive to the plowing speed and behavior of the relationship between plowing speed and effective field capacity and fuel consumption was as observed in literature.

\section{ACKNOWLEDGMENTS}

The author is grateful to ElBahloul Abdussalem, Lecture of programming, Shaqra University, Community College, Huraimla, Saudi Arabia for his valuable work in building C-Sharp application.

\section{REFERENCES}

Abbaspour-Gilandeh, Y., M. Omid and A. Keyhani (2007). Simulation program for predicting tractor field performance. World Applied Science Journal, 2(5):552 - 558.

Aboukarima, A. M. (2007). Draft models of chisel plow based on simulation using artificial neural networks. Misr J. Ag. Eng. 24 (1):42-61.

Ahmed, S. A. H. (2011). Effect of tractor forward speed on field performance of tillage implements. Unpublished M.Sc. Thesis, Department of Agric. Engineering, Faculty of Agriculture, University of Khartoum, Sudan, 92 p. 
Akinnuli, B. O. , F. O. Akerele and A. B.C. Nathanie (2014). Model developed for farm tractors and implements selection for optimum utilization. Journal of Emerging Trends in Engineering and Applied Sciences (JETEAS), 5(4): 248-255.

Al-Hamed, S., M. Wahby, A. Aboukarima and K. Ahmed (2014). Development of a computer program using visual basic for predicting performance parameters of tillage implements . Misr J. Ag. Eng., 31 (3): 1157-1190.

Al-Hamed, S.A. and A.A. Al-Janobi (2001a). A program for predicting tractor performance in visual $\mathrm{C}++$. Computers and Electronics in Agriculture, 31:137-149.

Al-Hamed, S.A. and A.A. Al-Janobi (2001b). An Object-oriented program to predict tractor and machine system performance. Res. Bult., No. (106), Res. Cent. Coll. of Agri., King Saud Univ., pp. (524).

Al-Hamed, S.A., R.D. Grisso, F.M. Zoz and K.Von Bargen (1994). Tractor performance spreadsheet for radial tires. Computers and Electronics in Agriculture, 10:45-62.

Al-Hamed, S.A., S.A. Al-Suhaibani, F.S. Mohammad and M.F.I Wahby (2010). Development of a comprehensive computer program for predicting farm energy. Am. J. Agric. Biol. Sci., 51:89-101.

Al-Janobi, A., S. Al-Hamed and A.M. Aboukarima (2010). An excel spreadsheet to estimate performance parameters for chisel plow tractor combination based on trained an artificial neural network. Bulletin USAMV Agriculture, 67(2):1-9.

AL-Mafrachi, A.A.A. H. (2015). Machinery Unit Energy Requirement and Fuel Consumption Tractor in Operation Tillage. International Journal of Advanced Multidisciplinary Research, 2(10):19-29.

Al-Suhaibani, S. A. and A. A. Al-Janobi (1997). Draught requirements of tillage implements operating on sandy loam soil. Journal of Agricultural Engineering Researches, 66:177-182.

Al-Suhaibani, S. A. and A. E. Ghaly (2013). Kinetic parameters of three chisel plows operating at different depths and forward speed in a 
sandy soil. The International Journal Of Engineering And Science (IJES), 2(7):42-59.

Al-Suhaibani, S. A., M. F. Wahby, A. M. Aboukarima and I. S. Tabash (2015). Study on the effect of soil moisture content and plowing speed on draft requirements of a moldboard plow. Journal of Advances in Agriculture, 4(3):477-486.

Al-Suhaibani, S.A. and A.E. Ghaly (2010). Performance evaluation of a heavy duty chisel plow at various tillage depth and forward speeds. American J. of Engineering and Applied Sciences, 3 (4): 588-596.

Al-Suhaibani, S.A., A.A. Al-Janobi and Y.N. Al-Majhadi (2010). Development and evaluation of tractors and tillage implements instrumentation system. Am. J. Eng. Applied Sci., 3: 363-371.

Altinigik, A. (2012). Analysis of tractor traction performance with artificial neural networks in cultivation. Unpublished $\mathrm{PhD}$ Thesis, T. C. Selcuk University, Institute of Science, Turkey. (Abstract in English).

ASABE (2000). ASAE Standards D497.4 Agricultural Machinery Management Data, In: ASAE Standards 2000, (372-380) St. Joseph, MI.

ASABE (2006). American Society of Agricultural and Biological Engineers (ASABE) Standards. Agricultural Machinery Management Data. ASAE D497.5 St Joseph Michigan. pp 391398,.

Askari, M. and S. Khalifahamzehghasem (2013). Draft force inputs for primary and secondary tillage implements in a clay loam soil. World Applied Sciences Journal, 21 (12): 1789-1794.

Askari, M., M.H. Komarizade, A.M. Nikbakht, N. Nobakht and R.F. Teimourlou (2011). A novel draft relationships for tillage and seeding three-point hitch dynamometer to measure the draft requirement of mounted implements. Research in Agricultural Engineering, 57: 128-136.

Bashir, M.A., M.I. Dawelbeit, M.O. Eltom and H. Tanakamaru (2015). Performance of different tillage implements and their effects on sorghum and maize grown in Gezira Vertisols, Sudan. 
International Journal Of Scientific \& Technology Research, 4(4):237-242.

Battiato, A., E. Diserens and L. Sartori (2013).Traction performance simulation for mechanical front wheel drive tractors: towards a practical computer tool. Journal of Agricultural Engineering,XLIV:(s2):e67:338-343.

Black, C.A., D.D. Evans, J.L. White, L.E. Ensminger and F.E. Clark (1965). Methods of soil analysis (part I). Amer. Soc. Agron. Inc., Madison, Wisconsin, USA: 375-377 and 552- 557.

Canakci, M., I. Unal and M. Topakci (2011). Development of computer software for determination of optimum tractor power and machinery sizes. Tarim Makinalan Bilimi Dergisi (Journal of Agricultural Machinery Science), 7(4):415-420.

Catalan, H., P. Linares and V. Mendez (2008). Tractor PT: A traction prediction software for agricultural tractors. Computers and electronics in agriculture, $6: 289-295$.

Crowell, G. and J.R. Bowers (1985). Southeastern tillage energy data and recommended reporting. Transactions of the ASAE, 28 (3):731737.

Cuplin, C. (1976). Profitable farm mechanization, 3rd Edition, published by Crosby Lockwood Staples, London, UK.

Edwards, W. (2007). Matching tractor power and implement size. Iwo State University, File A3-26 May 2007. www.extension.iastate.edu/agdm.

El-Ashry, E.R., A.M. Bassuni, A.A. Sayedahmed and K.A. Ahmed (1994). An Instrumentation system for measuring the tractor performance: I: system development and calibration. Misr. J. of Agric. Eng. 11 (4): 952 - 971.

Eldoma, I. M. (2008). Computer programming for farm machinery power estimation. Unpublished M.Sc. Thesis, University of Khartoum, Sudan.

Embaby, A. T. (1985). A comparison of the different mechanization systems for cereal crop production. M.SC Thesis, Faculty of Agriculture, Cairo University, Egypt. 
Gee-Clough, D., M. McAllister, G. Pearson and D.W. Evernden (1978). The empirical prediction of tractor - implement field performance. J. of Terramechanics, 15(2):81-94.

Grisso, R. D., M.Yasin and M. F. Kocher (1994). Tillage implement forces operating in silty clay loam. ASAE paper No.94-1532, St. Joseph, Mich., USA.

Grisso, R.D., D.H. Vaughan and G.T. Roberson (2006). Method for fuel prediction for specific tractor models. Paper No. 061089. In: The 2006 ASABE Annual International Meeting, Portland, Oregon, USA.

Gulsoylu, E., E. Cakir, E. Aykas, H. Yalcin, B. Cakmak and A. Cay (2012). Determination of the field performances of different types of chisel legs. Bulgarian Journal of Agricultural Science, 18 (5):794-800.

Hamod, A. I. and A. A. Essa (2010). The effect of inclination angles of disc plow and plowing speeds on some field technical indications and plowing profile gypsfreous soil conditions. Journal of University of Tikreet for Agricultural Sciences , 10(1):255-262. (In Arabic)

Hassan I. M., S. I. M. N. Gabir, M. A. A. Omer and O. M. Abbas (2011). A program for predicting performance of agricultural machinery in Visual Basic. Research Journal of Agriculture and Biological Sciences, 7(1): 32-41.

Hassann, M. M. A., I. M.M. Khater and B. Yasar (2009). Effect of field size on mechanical wheat seeder performance in reclaimed lands of Egypt. Tarim Makinalan Bilimi Dergisi (Journal of Agricultural Machinery Science), 5(1):45-51.

Ishola, T. A., A. O. Ogunlela and M. S. Abubakar (2010). An objectoriented program for matching tractors and implements. International Journal of Engineering \& Technology IJETIJENS, 10(2): 1- 4.

Ismail, W. I. W. and T.H. Burkhardt (1993). Draft and fuel requirements measurement using tractor on-board data acquisition system. Pertanika J. Sci. \& Techno., 1(1): 51-64. 
Jafari, R., S.H Karparvarfard and S.A. Hosseini (2011). The effect of geometry and motion characteristics of narrow tillage tool on soil disturbance efficiency. Journal of Agricultural Machinery Science, 7(3):253-258.

Kaul, M., R.L. Hill and C. Walthall (2005). Artificial neural network for corn and soybean prediction, Agricultural System, 85:1-18.

Kepner, R. A., R.Bainer and E. L. Barger (1978). Principles of farm machinery. 3rd ed. The AVI Publication Company , Inc, Westport, CT.

Korayem, A.Y., M. A. Shabon and E.R. El-Ashry (1985). Field performance of a chisel plow equipped with a secondary tillage uni.t Misr. J. Agric. Eng., 2 (4): 71 - 80.

Kumar, V., Y. S. Saharawat , M. K. Gathala, A. S. Jat , S. K. Singh, N. Chaudhary and M.L. Jat (2013). Effect of different tillage and seeding methods on energy use efficiency and productivity of wheat in the Indo-Gangetic Plains . Field Crops Research, 142:1-8.

Macmillan, R.H. (2002). The Mechanic of Tractor and Tillage Implement Performance. Theory and worked examples. University of Melbourne. Obtained from: http;//www. eprints.unimelb.edu.au.

Manuwa, S.I. and M.O Ogunlami (2010). Soil-tool interaction modeling of parameters of soil profile produced by tillage tools. J. Eng. and Applied Sci. , 5:91-95.

Marchant, J.A. Marchant and C.M. Onyango (2002). Comparison of Bayesian classifier with multilayer feed-forward neural network using example of plant/weed/soil discrimination. Computers and Electronics in Agriculture, 39(1):3-22.

Mehta, C.R., K. Singh and M.M. Selvan (2011). A decision support system for selection of tractor-implement system used on Indian farms. Journal of Terramechanics, 48:65-73

Meselhy, A. A. (2014). Performance evaluation of circular chisel plow in calcareous soil. International Journal of Emerging Technology and Advanced Engineering,4 (11):1-18.

Moeenifar, A., S.R M. Seyedi and D. Kalantari (2013). Determination of traction force acting on a wide blade using dimensional analysis Method. Intl J Agri Crop Sci.,5 (13):1403-1409. 
Mohamed, A.A.I, E.R. El-Ashry, Kh. A.A. Khader and AM. F. Bahnasy (2001). Design an instrumentation system to determine the tractor performance. Misr J. of Agric. Eng., 18 (3):527 - 536.

Mohamed, H. I., S. I. M. N. Gabir, M. A. A. Omer and O. M. Abbas (2011). A program for Predicting Performance of Agricultural Machinery in Visual Basic. Research Journal of Agriculture and Biological Sciences, 7(1): 32-41.

Naderloo, L., R. Alimadani, A. Akram, P. Javadikia and H. Z. Khanghah (2009). Tillage depth and forward speed effects on draft of three primary tillage implements in clay loam soil. Journal of Food, Agriculture \& Environment, 7 (3\&4):382-385.

Ndisya, J., A. Gitau, D. Mbuge and A.Hiuhu (2016). The effect of the operational parameters on the draft requirement of ripping in a sandy clay soil. Open Journal of Optimization, 5:1-13.

Omid, M. (2006). Introducing Simulation Software as an Educational Tool to Enhance Student Understanding of Tractor Field Performance. Int. J. Engng Ed., 22(6): 1219-1223.

PAES (2001). Philippine Agricultural Engineering Standard (PAES 121: 2001 Agricultural Machinery - Disk Plow - Specifications, 9 p.

Park, W.-Y. and S.-S. Lee (2012). Development of a tractive performance prediction program of tractors. Journal of Biosystems Engineering, 37(3):131-139 (abstact in English).

Patel, T., A. Chakravorty and S. Karmakar (2012). Software for performance prediction and matching of tractor-implement system. Emerging Trends and Applications in Computer Science (NCETACS), 2012 3rd National Conference, DOI:10.1109/NCETACS.2012.6203271:262 - 269.

Pranav, P. K., T. Patel, M. Rathore and A. J. Sonowal (2012). Computer simulation for haulage performance of power tiller. International Journal of Computer Applications,58(5):19-25.

Ranjbarian, S., M. Askari and J. Jannatkhah (2015). Performance of tractor and tillage implements in clay soil. Journal of the Saudi Society of Agricultural Sciences. http://dx.doi.org/10.1016/j.jssas.2015.05.003. 
Rashidi, M., I.Najjarzadeh, B.Jaberinasab, S. M. Emadi and M.Fayyazi (2013). Effect of soil moisture content, tillage depth and operation speed on draft force of moldboard plow. Middle-East Journal of Scientific Research, 16 (2): 245-249.

Sahu, R.K. and H. Raheman (2006). Draught prediction of agricultural implements using reference tillage tools in sandy clay loam soil. Biosyst. Eng., 94: 275-284.

Sahu, R.K. and H.Raheman (2008). A decision support system on matching and field performance prediction of tractor implement system. Computers and Electronics in Agriculture, 60:76-86.

Serrano Joao, M., J.O. Peca and F. Santos (2005). Draft and fuel requirement's in tillage operations: modeling for optimizing tractorimplement systems. EFITA/WCCA joint Congress in Agriculture, VILA Real, Portugal, pp. 831-836.

Sogaard, H.T. and C.G. Sorensen (1996). A model for optimal selection of machinery sizes within the farm machinery system. Sixth International Conference on Computers in Agriculture, American Society of Agricultural Engineers, St. Joseph, Michigan, USA: 588596.

Srivastava, A.K. (1993). Engineering Principles of Agricultural Machines. 1st Edn., American Society of Agricultural and Biological, St. Joseph, MI., pp: 601.

Tayel, M.Y., S. M. Shaaban and H.A. Mansour (2015). Effect of plowing conditions on the tractor wheel slippage and fuel consumption in sandy soil. International Journal of ChemTech Research,8(12):151-159.

Upadhyaya, S. K., T. H., Williams, L. J. Kemble and N. E. Collins (1984). Energy requirement for chiseling in coastal plain soils. Transactions of the ASAE, 27(6):1643-1649.

Wang, Y., F. Yang and Z. Yan (2014). Design and development of decision support system for equipping farm machines. Journal of Networks, 9(6):1648- 1655.

Younis S.M. and E.R. El-Ashry (1993). A mathematical model for predicting field capacity for agricultural machines. Alex. J. Agric. Res., 38 (2): 13-23. 
Younis, S.M., E.R. El-Ashry, A.F. Bahnasy and I.M. Elsybaee (2010). Development a local system for measuring tractors performance. Misr J. Ag. Eng., 27(1): 34-53.

Yousif, L. A., M. H. Dahab and H. R. El Ramlawi (2013). Cropmachinery management system for field operations and farm machinery selection. Journal of Agricultural Biotechnology and Sustainable Development,5(5):84-90.

Zaied, M.B., A. M. El Naim and T. E. Mahmoud (2014).Computer modeling for prediction of implement field performance variables. World Journal of Agricultural Research,2(2):37-41.

Zaied, M. B., A. M. El Naim, A. A. Omer and M. S. Abuobieda (2016). Effect of tine depth and width on soil failure angle, cutting coefficients and power in three-dimensional case: computer modeling. World Journal of Agricultural Research, 4(1):24-30.

Zarini, R. Loghmanpour, A. Akram, R. Alimardani and R. Tabatabaekoloor (2013). Development of decision support software for matching tractor implement system used on Iranian farms. American Journal of Engineering Research (AJER), 2(7):8698.

Zoz, F. M. and R.D. Grisso (2003). Traction and Tractor Performance. The 2003 Agricultural Equipment Technology Conference Louisville, Kentucky, USA 9-11 February 2003.
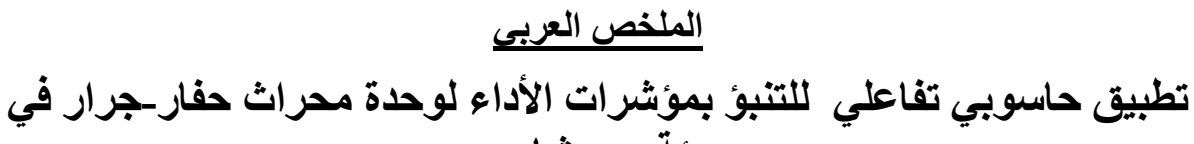

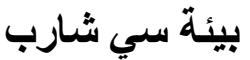

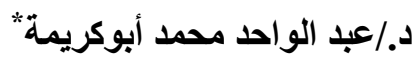

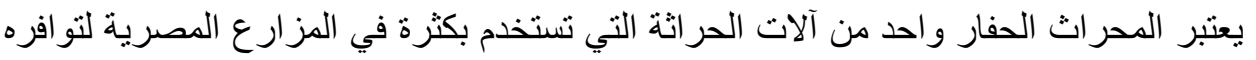

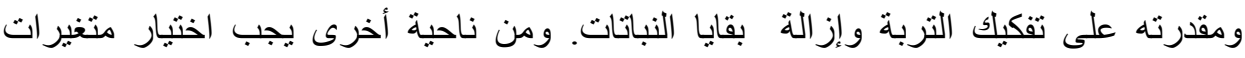

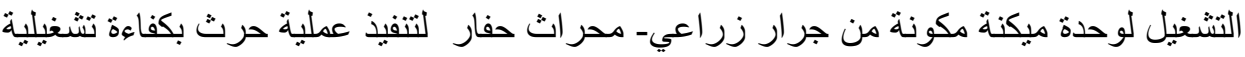

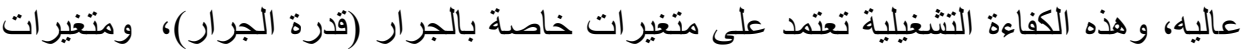

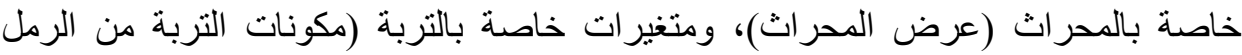

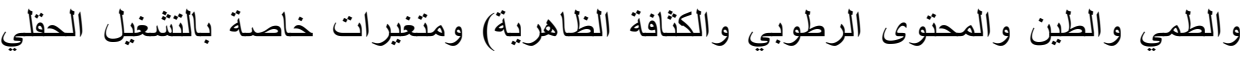

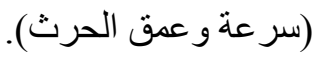

"باحث أول، معهد بحوث الهندسة الزراعية، مركز البحوث الزراعية، ج.م.ع 
وفي المقابل لاختيار هذه المتغير ات، ينت الاعتماد على الخبرة أو تنفيذ تجربة للتأكد من أن عملية

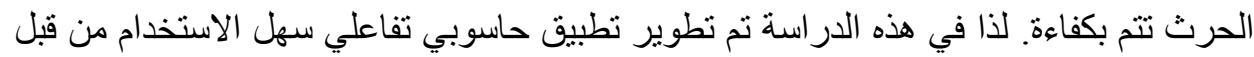

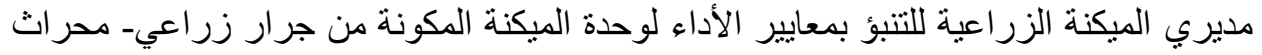

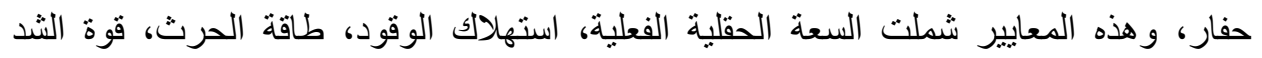

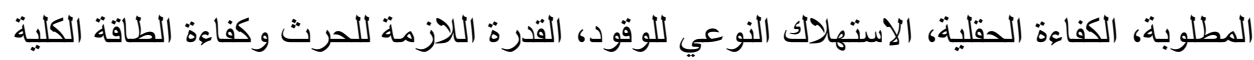

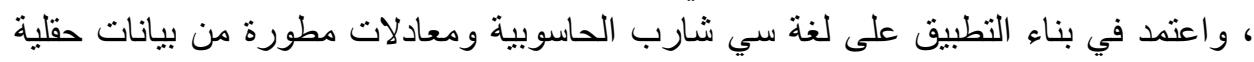

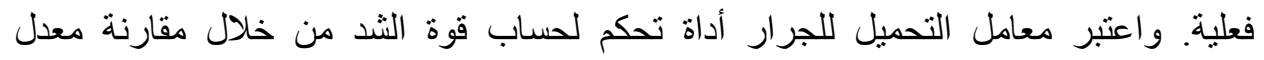

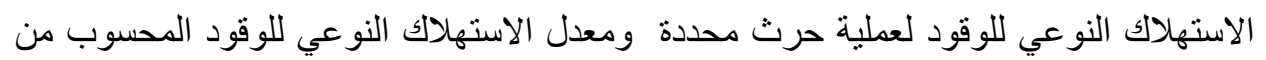

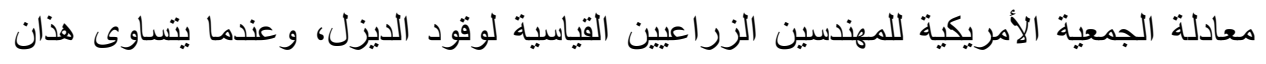

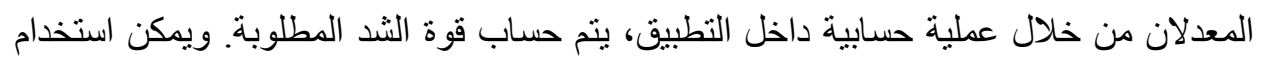

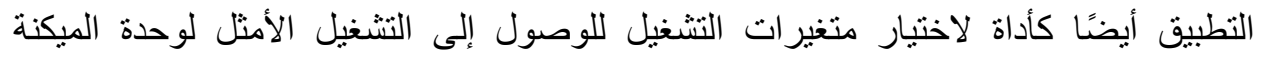

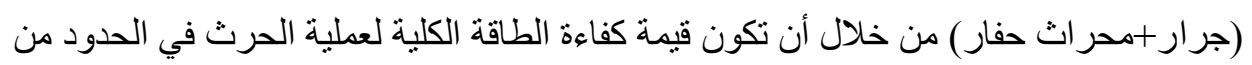

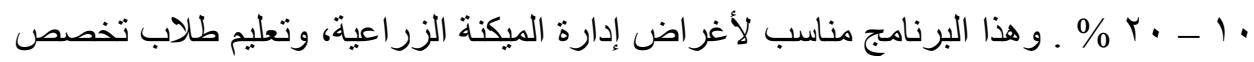

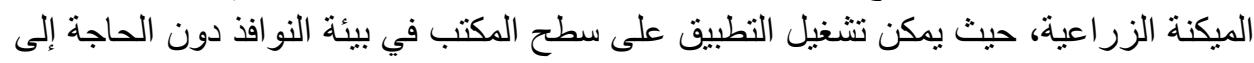

$$
\text { وجود لغة سي شارب الحاسوبية. }
$$

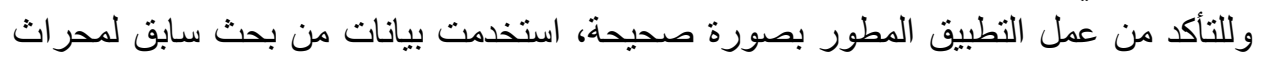

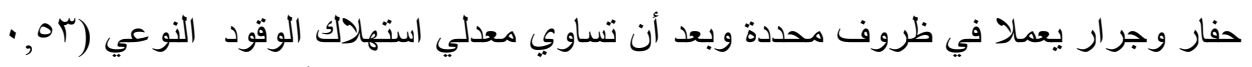

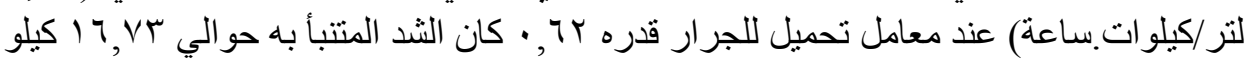

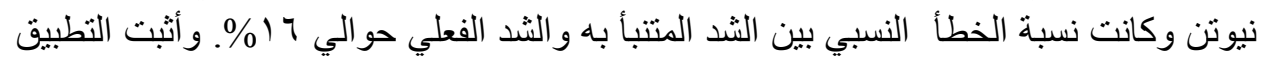
سهولة استخدامه من أجل الغرض الذي صمح من أجله. 